\title{
Interaction of host and Staphylococcus aureus protease-system regulates virulence and pathogenicity
}

\author{
Vigyasa Singh $^{1} \cdot$ Ujjal Jyoti Phukan ${ }^{2}$
}

Received: 1 June 2018 / Accepted: 22 November 2018 / Published online: 27 November 2018

c) Springer-Verlag GmbH Germany, part of Springer Nature 2018

\begin{abstract}
Staphylococcus aureus causes various health care- and community-associated infections as well as certain chronic TH2 driven inflammatory diseases. It is a potent pathogen with serious virulence and associated high morbidity. Severe pathogenicity is accredited to the $S$. aureus secreted virulence factors such as proteases and host protease modulators. These virulence factors promote adhesion and invasion of bacteria through damage of tight junction barrier and keratinocytes. They inhibit activation and transmigration of various immune cells such as neutrophils (and neutrophil proteases) to evade opsono-phagocytosis and intracellular bacterial killing. Additionally, they protect the bacteria from extracellular killing by disrupting integrity of extracellular matrix. Platelet activation and agglutination is also impaired by these factors. They also block the classical as well as alternative pathways of complement activation and assist in spread of infection through blood and tissue. As these factors are exquisite factors of $S$. aureus mediated disease development, we have focused on review of diversification of various protease-system associated virulence factors, their structural building, diverse role in disease development and available therapeutic counter measures. This review summarises the role of protease-associated virulence factors during invasion and progression of disease.
\end{abstract}

Keywords Staphylococcus aureus $\cdot$ Virulence factors $\cdot$ Proteases $\cdot$ Modulators of proteases $\cdot$ Regulators of immune cells

\section{Introduction}

Staphylococcus aureus is gram-positive facultative anaerobe that colonizes human body and acts as a commensal [1,2]. $S$. aureus causes various acute infections such as health careand community-associated diseases including pneumonia, cutaneous lesions, toxic shock syndrome and osteomyelitis $[3,4]$. S. aureus also acts as pathobionts as they are associated with certainchronic $\mathrm{TH} 2$-biased inflammatory diseases,

Edited by: C. Bogdan.

Ujjal Jyoti Phukan

ujjwal.phukan@gmail.com

Vigyasa Singh

vigyasa105@gmail.com

1 Molecular Bioprospection Department, CSIR-Central Institute of Medicinal and Aromatic Plants, P.O. CIMAP, Lucknow 226015, India

2 School of Life Science, Jawaharlal Nehru University, New Delhi 110067, India such as atopic dermatitis (AD) and chronic rhinosinusitis with nasal polyps [5-7].

Various factors regulate the virulence and pathogenicity of $S$. aureus $[8,9]$. These factors activate virulence and metabolic pathways of bacteria to ensure its survival [10, 11]. The host immune responses are actively modulated by these factors to induce immunosuppressive effect on target areas $[12,13]$. One of the major factors involved in invasion and colonization of the bacteria is the proteases system [14, 15]. Through 'protease system' we are trying to emphasize on every component of host and microbe that either regulates or regulated by proteases. Proteases can cleave specific components of host immune system, disrupt integrity of extracellular matrix/intercellular connections and counteract epithelia defense actions $[16,17]$. Some $S$. aureus secreted factors can bind and regulate host protease precursors to inhibit phagocytic killing by neutrophils in blood as well as macrophages in tissues [18, 19].

Therefore, to understand the mechanism of host-microbe interaction it is necessary to study the interplay of protease system in host and bacteria. Our goal is to address the recent development and research made in this area to the 
best of our knowledge to compile a comprehensive review. Our emphasis will be to highlight the importance of proteases, their inhibitors or activators and the potential ways to regulate virulence as well as pathogenicity through factors secreted by bacteria that modulate host proteases for disease development.

\section{Regulatory locus of virulence factors}

Staphylococcus aureus virulence factors are governed directly or indirectly by various regulatory locus such as $\operatorname{agr}$ (accessory gene regulator), sarA (S. aureus accessory regulatory) homologues, sae ( $S$. aureus exoprotein expression) and $\operatorname{SigB}$ (alternative sigma factor B) [20]. A brief description is given below.

\section{agr locus}

Staphylococcus aureus agr locus is a quorum-sensing gene cluster that regulates various virulence and cell wall associated factors [21]. In a study by Ziebandt et al. [22] showed that agr modulates expression of over 70 genes in $S$. aureus and 23 of them (including various proteases such as Aur, Spls, SspA and SspB) are known to directly involved in its virulence. The locus contains mainly two transcripts RNAII and RNAIII. RNAII covers the agrABCD operon (involves in secretion, maturation, export of auto-inducing peptideAIP that activates a classical two-component signal transduction system-TCSTS) and is regulated by $\mathrm{P} 2$ promoter. RNAIII (encodes $\delta$-hemolysin-hld) is the effector molecule of agr operon and is regulated by $\mathrm{P} 3$ promoter [23]. $a g r$ locus is also activated by the RAP-TRAP (RNAIII activating protein-target of RAP) two-component system while it is inhibited by RIP- RNAIII inhibiting peptide [24]. RNAIII upregulates various genes associated with bacterial invasion such as leukocidins, enterotoxins ( $\alpha$-toxin, $\beta$-hemolysin, Toxic shock syndrome toxin 1, leucotoxins), exoproteases and lipases while downregulates genes involved in colonization such as surface adhesins, protein A, coagulase and fibronectin binding protein [25]. RNAIII regulates expression of these virulence factors both at the transcriptional and translational levels [24].

\section{sar locus}

The sar locus contains three overlapping transcripts (sarA $\sim 0.56 \mathrm{~Kb}, \operatorname{sarC} \sim 0.8 \mathrm{~Kb}$ and sarB $\sim 1.2 \mathrm{~Kb}$ ) encoding sarA ORF [26, 27]. sar upstream region contains three distinct promoters (P2, P3 and P1) from which these transcripts originate. $s a r A$ is a DNA binding protein that promotes $a g r$ mediated regulation of virulence factors by specifically binding to the $\mathrm{P} 2$ promoter region of $a g r$ and to a lesser extent to
P3 promoter region. It forms a homodimer that interacts with the conserved A/T-rich recognition motifs present in the promoters of target genes. sar also works independent of $a g r$ and interact directly wth the SAR boxes of the promoters of various cell wall-associated proteins (protein A, fibronectinbinding proteins, collagen adhesin) and exoproteins [24]. It up-regulates $\alpha$-hemolysin and represses V8 protease [28]. According to Dunman et al. [29] sarA regulates directly or indirectly over 120 genes. Some $\operatorname{sar} A$ homologus regulatory locus are also present in $S$. aureus such as sarR, sarS, sarT and $\operatorname{sar} U$ that regulates various virulence factors.

\section{sae locus}

sae is an important regulator of various virulence factors associated with bacterial adhesion, immune modulation or toxicity [30, 31]. Various studies including microarray and proteomics analysis revealed coa (coagulase), hla ( $\alpha$-toxin) and or $f n b A$ (fibronectin-binding protein A) are regulated by sae [32]. sae locus regulates gene expression primarily at the transcriptional level unlike agr [24]. Transcriptional analysis showed that sae locus constitutes a four-component regulator system with protein-encoding regions (saeR, saeS, ORF3 and ORF4). saeS is a membrane-spanning sensor histidine kinases (composed of a signal binding domain and an autokinase domain) and sae $\mathrm{R}$ (composed of an $\mathrm{N}$-terminal regulatory domain and the $\mathrm{C}$-terminal effector domain) is a cognate cytosolic response regulator [33]. saeS-saeR acts as a bacterial two-component system in which saeS autophosphorylates upon appropriate signal and then activates saeR. In addition, three overlapping transcripts $(\mathrm{T} 1 \sim 3.0 \mathrm{~Kb}$, $\mathrm{T} 2 \sim 2.4 \mathrm{~Kb}$ and $\mathrm{T} 3 \sim 2.0 \mathrm{~Kb}$ ) and one independent transcript $(\mathrm{T} 4 \sim 0.7 \mathrm{~Kb})$ are found in the sae operon. sae upstream region consists of 2 distinct functional promoters (P1 and $\mathrm{P} 3)$. sae transcription is mainly driven $\mathrm{P} 1$ promoter that is strongly autoregulated, activated by $a g r$, and repressed by sigma factor B [34]. On the other hand, sae does not affect the expression of agr or sarA. sae locus is reported to be influenced by environmental factors (low $\mathrm{pH}$, high $\mathrm{NaCl}$ concentration and sub-inhibitory concentrations of antibiotics) [35].

\section{SigB locus}

It is a stress response and stationary-phase sigma factor that enhances transcription of genes that can confer resistance to heat, oxidative and antibiotic stresses [36]. SigB directly controls expression sarA promoters, and indirectly of $a g r$. SigB also exerts a negative effect on agr expression (RNAIII) independently of SarA [37]. SigB is also necessary for bacterial aggregation and it is mediated by regulating expression of the genes such as clumping factor and adhesins [24]. 


\section{Types of S. aureus proteases and their role in disease development}

To manipulate the host immune responses $S$. aureus secretes various proteases such as cysteine proteases, serine proteases, serine protease-like proteins and metallo-proteinases. Earlier it was thought that these proteases assist in the acquisition of nutrients but recent reports have indicated that they interact with neutrophils, plasma proteins and antimicrobial peptides to weaken host immunity [38, 39]. Expression and synthesis of these proteases is mainly modulated by two global regulatory elements, one is sarA (staphylococcal accessory regulator) and other one is agr (accessory gene regulator). agr expression is directly or indirectly regulated by sarA which in turn modulates virulence determinant synthesis [40].

\section{Cysteine proteases}

These are papain-like cysteine proteases (staphopains) that belong to the family $\mathrm{C} 47$ of clan CA of cysteine peptidases. Three-dimensional structure shows a papain-like fold with two domains L- and R-. The N-terminal part represents the L-domain that contains the active site helix carrying a nucleophilic cysteine. The $\mathrm{R}$ domain is built around a size-stranded antiparallel pseudobarrel that carries the catalytic histidine and asparagine residues [41]. Staphopains can directly or indirectly damage the epithelium as well as underlying connective tissue [42]. There are two cysteine proteases identified staphopain A (ScpA) and staphopainB (SspB).

\section{ScpA}

ScpA is a $20 \mathrm{kDa}$ protein that degrades elastin, collagen, fibrinogen, fibronectin and kininogen present in tissues [43, 44]. It is synthesized as zymogen and then this inactive precursor is self-activated outside the cell [45]. ScpA significantly affects neutrophils (major component of the innate immune response regulated by cytokines and chemokines), which plays an important role in the interaction of $S$. aureus and host [46, 47]. ScpA impairs movement as well as the activation of neutrophils towards CXCR2 chemokines (interleukin- 1 to -7 that possess an E-L-R amino acid motif and a CXC motif, which binds to the CXCR2 integral neutrophil membrane protein, Fig. 1a). It does soby cleaving N-termini of CXCR2 integral protein present on neutrophil membranes $[48,49]$. It also inactivates $\alpha$-1-protease inhibitor and $\alpha$-1-antichymotrypsin as shown in Fig. 1a [50]. ScpA is reported to inhibit the classical

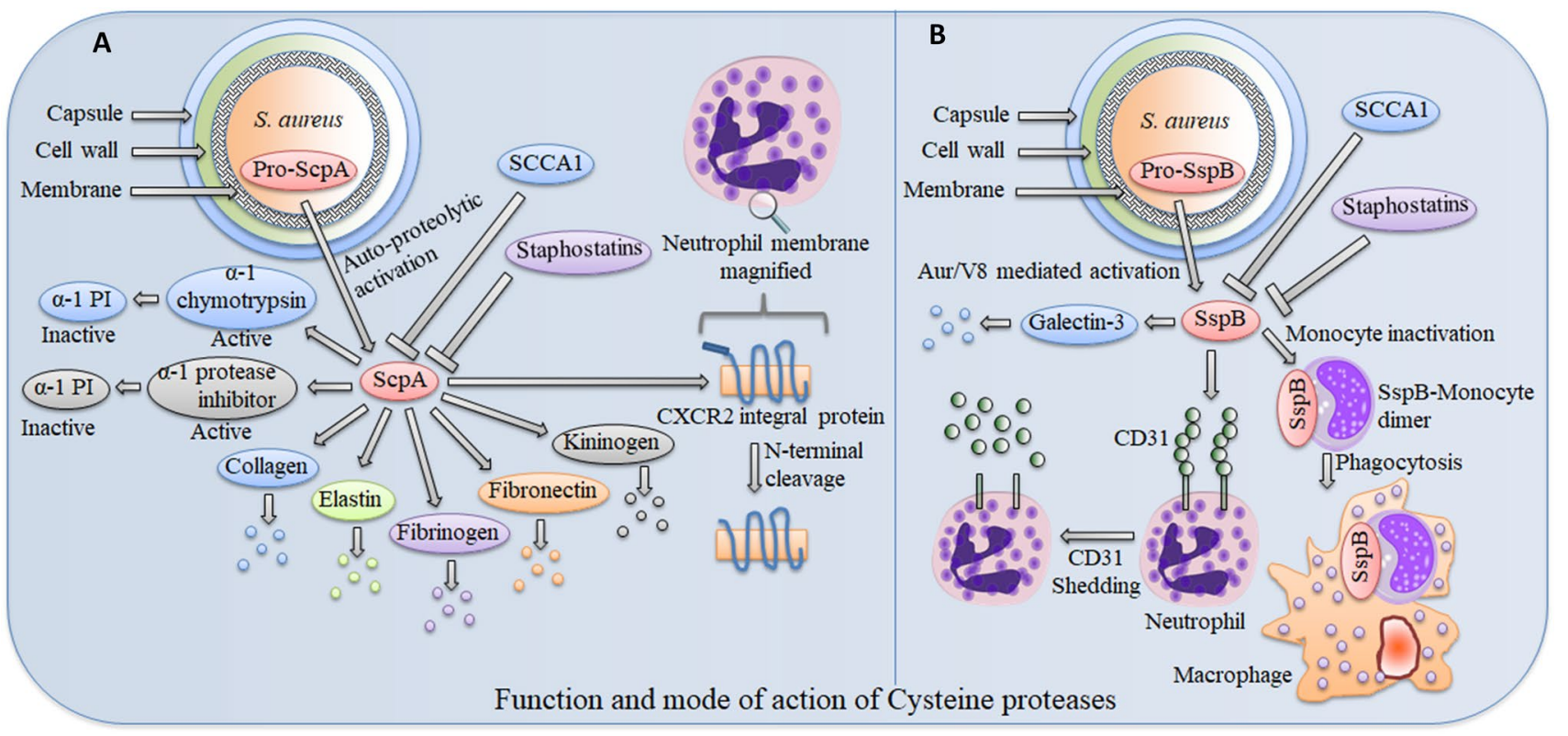

Fig. 1 Function and mode of action of Cysteine proteases. a Role of ScpA in host immune regulation. Immature ScpA (Pro-ScpA) is secreted out of pathogen and processed through autocatlytic activation. Active enzyme cleaves CXCR2 integral membrane protein of neutrophils and impairs neutrophil migration. It inactivates protease inhibitors ( $\alpha$-1-protease inhibitor and $\alpha$-1-antichymotrypsin), proteins of extracellular matrix (elastin, collagen, fibrinogen and fibronectin) and kininogen. It is inhibited by endogenous staphostatins and human serpin SCCA1 (Squamous Cell Carcinoma Antigen 1). b Role of $\mathrm{SspB}$ in host immune regulation. Immature SspB (Pro-SspB) is secreted out of pathogen and processed through Aur mediated activation. Active enzyme sheds of CD31 from neutrophils imparing removal of aged neutrophils. It promotes monocyte inactivation and phagocytosis by macrophages by forming a monocyte-SspB dimer. It also inhibits immune responsive protein galectin-3. Its inhibitors are staphostatins and SCCA1 
as well as alternative pathways of complement activation [51]. Human epithelial-derived serpin SCCA1 (Squamous Cell Carcinoma Antigen 1) can inhibit the activity of staphopains in-vivo at epithelial surfaces infected by S. aureus (Fig. 1a). SCCA1 interacts with ScpA forming a covalent complex in which the enzyme and inhibitor are linked by a thio-ester bond. Then ScpA cleaves the peptide bond present between Gly354-Ser355 and releases the C-terminal 4.5 kDa serpin fragment. This suicide substrate mechanism is called reactive site loop (RSL) cleavage of the inhibitor by the protease that makes the enzyme inactive [52]. Another endogenous novel class of ScpA protease inhibitors is low molecular weight analogues of staphostatins (A \& B, Fig. 1a). These highly specific homologues occlude the active site of ScpA in a substratelike manner forming a long-lived inhibitor-enzyme complex and rendering the enzyme inactive [52]. Therefore, anlagos of these endogenous protease inhibitors can be screened and potent anti-ScpA drugs can be developed for abrogating the activity of these proteases, and thus virulence development.

\section{SspB}

SspB is also $20 \mathrm{kDa}$ and structurally similar to ScpA though having significant difference in their nucleotide sequence. $\mathrm{SspB}$ is too produced as zymogen but its activation depends on Aur (aureolysin- a metalloproteinase) mediated proteolytic activation of a serine protease V8 or SspA [45]. As shown in Fig. $1 \mathrm{~b}$ it interacts with the neutrophils and sheds of CD31 (cluster of differentiation 31, also known as Platelet endothelial cell adhesion molecule- PECAM1, involved in transmigration of leukocyte, angiogenesis, removal of aged neutrophils and activation of integrin) from its surface [39, 53]. It causes imbalance in the homeostasis of host immune cells in the inflamed tissue. SspB also hampers the antibacterial response of monocytes by repressing their chemotactic activity and by forming a dimer of SspB-monocyte [9]. These SspB conjugated monocytes are subsequently phagocytized by macrophages (Fig. 1b) leading to further dampening of immune system and vigorous colonization of bacteria [39]. Human galectin-3 is an immune responsive $\beta$-galactosidebinding lectin protein [54]. It provides antimicrobial defense by activating neutrophil NADPH oxidase and inducing ROS production in neutrophils [55]. SspB is reported to hydrolyze galectin-3 and inhibit its opsonizing and bacteriostatic properties (Fig. 1b) [56]. Similar to ScpA, SspB activity is also inhibited by SCCA1 and staphostatins as shown in Fig. 1b.

\section{Serine protease}

\section{SspA}

The serine protease (SspA or V8 or GluV8) was first purified from $S$. aureus strain V8 that belong to the family of glutamyl endopeptidase [57]. SspA is similar to pancreatic serine proteases without the disulphide bridges. It also shares high structural homology of the active site with other serine proteases such as epidermolytic toxins and trypsin [58]. It is secreted as an inactive precursor and Aur is required for activation as well as maturation of this protease (Fig. 2) [45, 59]. SspA specifically targets peptide bonds present on the carboxyl side of glutamate (and aspartate, to a lesser extent) residues of all immunoglobulin classes [9]. As shown in Fig. 2 SspA degrades the Fc region of immunoglobulins that disturbs the effector function and leads to partial loss of antigenic determinants of the antibody. It blocks and impairs the interaction of cell surface antigens to immune effector cells mediated by immunoglobulins [60]. Cleavage of IgG hinge by $\mathrm{SspA}$ hinders cellular and humoral immune responses induced by pathogens $[61,62]$. Staphylococcal binder of immunoglobulin (Sbi) also interacts with the $\mathrm{Fc}$ region of IgG and enhances this immune-suppressor response (Fig. 2) $[63,64]$. To counteract this invasion tactic of pathogens, host releases anti-hinge autoantibodies that specifically interact with cleaved IgGs and restore $\mathrm{Fc}$-mediated cell-killing functions $[65,66]$. It is reported that the production of anti-hinge antibodies can be boosted by an immunization strategy of pathogen-mediated proteolysis of host IgGs. When animals were immunized with peptide analogs of the cleaved IgG hinge, significant reduction in $S$. aureus colony formation was observed. This substrate specificity is attributed to the positively charged N-terminus of the enzyme. Broad-spectrum inhibitor Pefabloc SC is reported to inhibit activity of SspA (Fig. 2) [56]. It is reported that a single mutation in SspA impart a modest impact on the daptomycin antibiotic tolerance in MRSA [67].

It is reported that SspA is significantly secreted during the development of $\mathrm{AD}$ (a common chronic relapsing inflammatory skin disease) infection [68]. SspA affects skin integrity by damaging stratum corneum in murine model in in-vivo conditions $[40,69,70]$. Recently it is shown that tight junction damage and impairment of barrier integrity by SspA is caused by keratinocyte damage as shown in Fig. 2 [71]. $\mathrm{AD}$ induces the expression of proinflammatory cytokine IL-1 $\beta$ that in turn activates production of antimicrobial/ host defense peptides (HDPs) such as $\beta$-Defensins (human $\beta$-defensin 2-hBD2) [72]. Soluble protective factor hBD2 inhibits SsspA (Fig. 2) and is sufficient to protect keratinocytes against SspA mediated damage [68]. This protective phenotype of hBD2 against SspA-induced skin barrier dysfunction can be targeted for therapeutic applications instead of corticosteroids to restore skin lesion.

\section{Epidermin leader peptide processing serine protease (EpiP)}

It acts as a subtilisin-like serine protease that can cleave both casein and collagen (Fig. 2) [73, 74]. It possesses a 


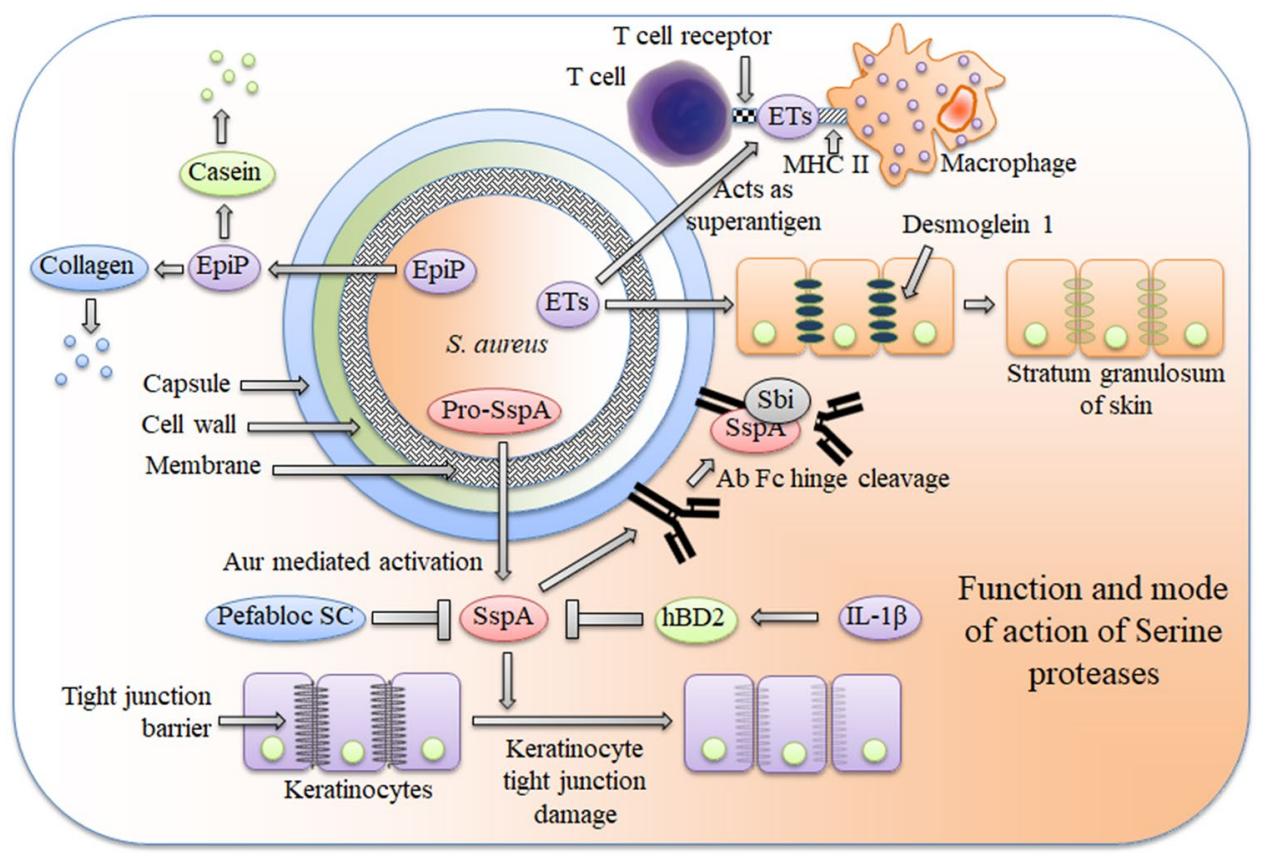

Fig. 2 Function and mode of action of serine proteases. Immature SspA (Pro-SspA) is secreted out of pathogen and processed through Aur mediated activation. Active enzymealong with Sbi (Staphylococcal binder of immunoglobulin) blocks and impairs immunoglobulins by degrading their Fc region. It dampens barrier integrity by damaging tight junction in the karatinocytes. Antibiotic pefabloc-Sc and

peptidase-S8 domain carrying the catalytic triad of Aspartic acid, Histidine, and Serine. It also has an N-terminal prodomain (having $4 \beta$ strands flanked by $2 \alpha$ helices) and a $\mathrm{C}$-terminal protease domain (having subtilisin-like serine protease fold). In the extracellular matrix it is secreted as a zymogen and then processed by an autocatalytical intramolecular mechanism. It shows homology to the extracellular epidermin leader peptidase of $S$. epidermidis that mediates proteolytic processing of the mature 1-antibiotic (peptide antibiotics/bacteriocins containing polycyclic thioether amino acids-lanthionine or methyllanthionine) epidermin. Though epidermin synthesis is not sure in S. aureus, EpiP provide increased virulence through some unknown mechanism. Vaccination with a recombinant EpiP (rEpiP) and a noncleaving mutant (rEpiP-S393A) peptide significantly reduced $S$. aureus infection in mice [74]. EpiP also shows homology with Streptococcus pyogenes SpyCEP protease that impairs IL- 8 by cleaving its C-terminal fragment. It leads to inhibition of neutrophil recruitment at the locus of bacterial infection $[75,76]$.

\section{Exfoliative toxins (ET)}

These are serine proteases carrying chymotrypsin family catalytic triad of Serine, Histidine and Aspartate residues [77]. $S$. aureus possesses two main biologically, antigenically defense peptide hBD2 (human $\beta$-defensin 2) inhibits SspA activity. ETs acts as superantigens and mediate interaction between T-cell receptor and MHC-II of macrophages. ETs also cleave Desmoglein 1 required for cell-to-cell keratinocyte adhesion impairing membrane integrity. EpiP cleaves casein and collagen

and serologically distinct ETs namely ETA $(26.9 \mathrm{kDa}$, heat stable, located on chromosome) and ETB (27.2 kDa, heatlabile and located in large plasmid). X-ray crystallography structure shows two main domains (S1 and S2) made of sixstrand $\beta$-barrels and a C-terminal $\alpha$-helix $[78,79]$. The active site carrying the catalytic triad is located on the interface of two barrels [80]. They possess esterolytic activity (intrinsic $\mathrm{N}$-t-butyloxycarbonyl-L-glutamic acid alpha-phenyl esterase activity) and mitogenic activity but their mitogenic activity is independent of their proteolytic activity [81]. ETs reported to cause skin infections such as staphylococcal scalded skin syndrome in newborns, old people and immunocompromised patients [82]. Broad-spectrum serine protease inhibitor DFP (diisopropylphosphorofluoridate) impairs esterolytic activity of ETB but not ETA. As shown in Fig. 2, ETs are also reported to be superantigens (proteins that interact simultaneously with the T-cell receptor and to the major histocompatibility complex class II, leading to induction of T cells expressing specific $\mathrm{V} \beta$ subsets of the TCR repertoire). ETs specifically cleave Desmoglein 1 (a desmosomal glycoprotein of cadherin superfamily that mediates keratinocyte cell-to-cell adhesion in the stratum granulosum of the skin) but not Desmoglein 3 (Fig. 2) [83, 84]. Hydrolysis of Desmoglein 1 depends upon its proper conformation as unfolded protein is not cleaved [85]. ETs cause staphylococcal scalded skin syndrome (SSSS) and bullous impetigo. Symptoms of 
the diseases include severe loss of superficial skin layers, blister formation, dehydration and secondary infections [86]. ETs share high homology with SspA and both probably act together to disrupt stability and barrier function of the skin through desmoglein1 degradation [87].

\section{Serine protease-like proteins (Spls)}

S. aureus secretes 6 serine protease-like proteins (SplA$\mathrm{SplF}$ ) that are encoded in a single operon known as $\nu \mathrm{Sa} \beta$ pathogenicity island $[88,89]$. All Spls share high sequence homology and they are specific for $S$. aureus only [90, 91]. They are referred as serine protease-like proteins because they show significant amino acid homology with SspA protease and ETs [90, 92, 93]. Spls are directly regulated by sae ( $S$. aureus exoprotein expression locus that modulates various virulence factors) regulatory system [94-96]. They posses a signal peptide and chymotrypsin-like fold that contains two domains consisting of six antiparallel $\beta$ strands folded into a $\beta$ barrel. Active site of Spls carries Histidine, Aspartic acid and Serine in the interface of two $\beta$ barrels [97, 98]. Upon docking of a substrate containing the consensus sequence motif Tryptophan-Glutamic acid-LeucineGlutamine, Spls form a oxyanion hole in their three dimensional structure [99]. Spls are reported to have individual and very unique protease activity as they target specific proteins involved in host-pathogen interaction rather than general bacterial nutrition [93, 98, 99]. Spls trigger TH2 cytokines and elicit production of $\operatorname{IgE}$ antibody in response to allergens [100]. They are released as soluble proteins in considerable amounts so that they can be sequestered from the adjuvant bacterial cells, which can drive a TH1/TH17 response (that may override the Spl effects).

Spls are reported to be active in various common chronic diseases such as asthma and pneumonia causing disseminated lung damage [9]. These proteases along with $\alpha$-hemolysin (pore-forming toxin) lead to dysfunction of epithelial barrier facilitating allergen invasion and subsequent allergy response. In a study systematic analysis of virulence factors identified Spls that impose strongest and frequent induction of human immune memory of proteins mostly allergen-specific IgE antibodies [101]. Spls significantly aggravate chronic allergic inflammation by enhancing the pre-existing TH2-bias and cytokine (mainly IL-4, IL-5, and IL-13) response. It induces anti-inflammatory cytokine IL-10 but do not elicit IFN-g, IL-6, TNF, and IL-17 [101]. Spls also elicit IgG4 antibody activity. Analysis of Hla (an immunomodulatory virulence factor and a potent cytolysin) activity in $\Delta$ spl::erm (allelic replacement spl operon mutant) reveals that hemolysis is unaffected by the Spls $[102,103]$. Analysis of surface proteomic of wild type and $\Delta$ spl::erm revealed various virulence factors (complement inhibitors, hemolysins, adhesins) regulated by Spls [104].

\section{SpIA}

SplA is reported to promote bacterial invasion and spread in the lung tissues by cleaving a glycosylated cell surface protein mucin 16 [104]. Mucin 16 is a 25-MDa, cell surface protein that is heavily glycosylated and acts as a protective barrier against pathogens through lubrication of epithelia [105]. Analysis of 3D structure and investigation of substrate cleavage site revealed that SplA has specific preference for W/Y-L-Y $\downarrow$ T/S (Trp/Tyr-Leu-Tyr-Thr/Ser) motif. It cleaves mucin 16 at Y-L-Y-S site and induces shedding of mucin 16 from epithelia (Fig. 3a) [106, 107]. Mucin 16 is also present in epithelial cells of ocular surface, airway and female reproductive tract epithelia [108]. Mucin 16 impaired human epithelial cell lines showed more susceptibility towards bacterial colonization and invasion [109]. When treated with a serine protease inhibitor 3,4-DCI (3,4-dichloroisocoumarin), it significantly reduced this shedding effect. This shedding property of SplA upsets integrity of airway epithelial barrier and promotes disease development [110].

\section{SplB}

It belongs to the chymotrypsin family of serine proteases (family S1, small subfamily S1B). No known targets of SplB have been identified but transmembrane sensory proteins olfactory receptor could be a potential target of these proteases as they contain W-E-L-Q motif in their sequence [99]. SplB has been shown to stimulate specific antibody production in staphylococcal liquid culture [111]. They are devoid of any propeptides so it is difficult to obtain their potential inhibitors. Though it has a signal peptide that imposes an inhibitory effect [97]. Crystal structure of zymogen and mature enzyme does not offer any major conformational change in the active site. Only a unique network of hydrogen bonds distant form the active site is formed by the new N-terminal glutamic acid of mature SplB [97]. Apart from inhibiting the SplB activity, the signal peptide mediates targeting of SplB into extracellular compartment. Proteolytic activity of SplB is triggered by signal peptidase only upon secretion. Rearrangements due to hydrogen bonding formation orchestrate a substrate binding cleft and an oxyanion hole in the mature enzyme. In a study novel $\alpha$-aminophosphonic analogues of glutamine and their peptidyl derivatives have been tested. One of the compoundsCbz-Glu-Leu-Gln ${ }^{\mathrm{P}}\left(\mathrm{OC}_{6} \mathrm{H}_{4}-4-\mathrm{O}-\mathrm{CH}_{3}\right)_{2}$ - displayed an apparent second-order inhibition rate value of $1400 \mathrm{M}^{-1} \mathrm{~s}^{-1}$ [112].

\section{SpID}

Potent activity of SplD is reported during various allergic responses. It causes increased airway hyper-reactivity and greater mucus production in allergic airway in mice. It has 


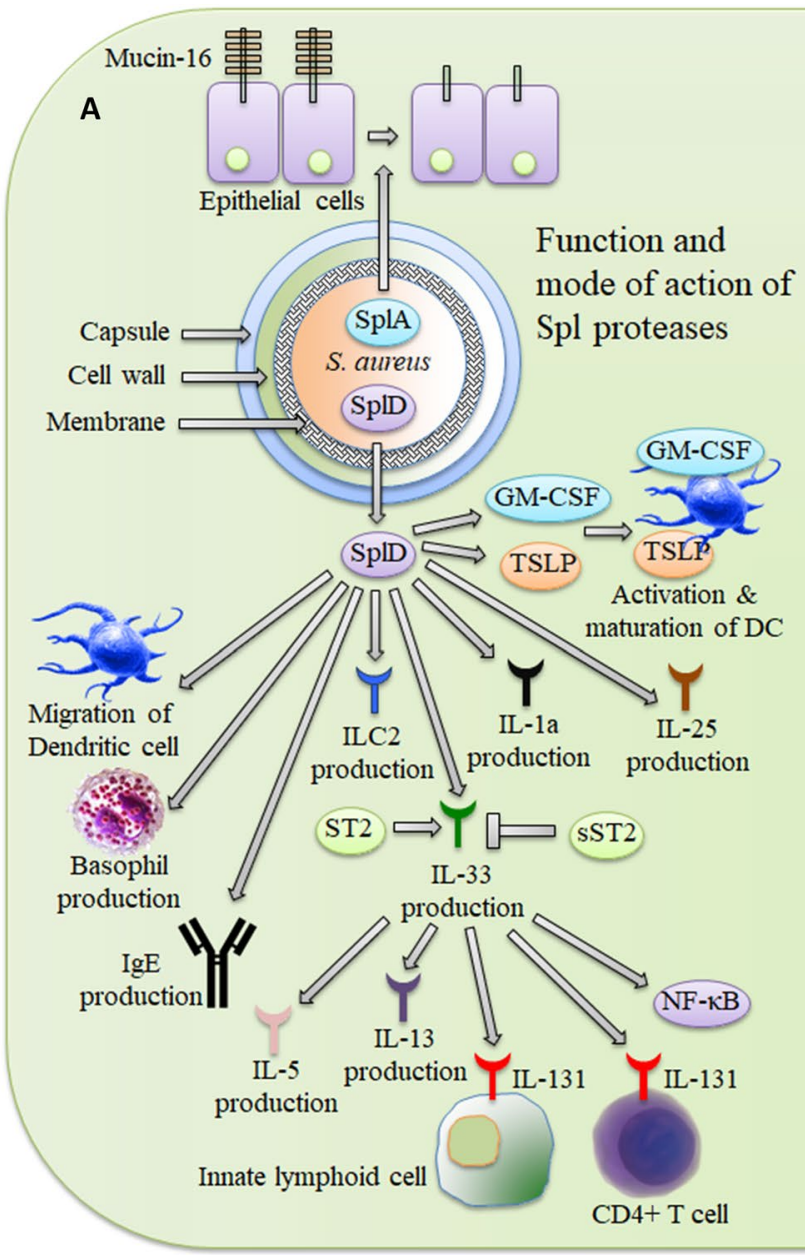

Fig. 3 Function and mode of action of Spl and Aur proteases. a Role of Spls in host immune regulation. SplA cleaves glycosylated cell surface protein mucin 16 that acts as a protective barrier against pathogens. SplD mediates allergy response by activating production of IL-1a, IL-25, TSLP (thymic stromal lymphopoietin), GMCSF(Granulocyte-macrophage colony-stimulating factor), IgE and basophil. SplD also promotes maturation and migration of dendritic cells. SplD induces IL-33 production which then regulates various downstream factors such as NF- $\kappa B$, IL-5, IL-13, innate lymphoid cells and CD4 $+\mathrm{T}$ cells. Il-33 mediated response is induced by ST2 while inhibited sST2 (soluble suppression of tumorigenicity 2). b

the more target specificity than SplA and SplB. It preferentially cleaves targets on R-Y/W-P/L-T/L/I/V $\downarrow S$ residues but can also cleave substrates with slight variation in these residues [93]. During idiopathic or severe asthma S. aureus releases enterotoxins (superantigens that have potent mitogenic activity on $\mathrm{T}$ cells) that are $\operatorname{IgE}$ antibodies specific $[113,114]$. Production of SplD-specific IgE (as well as eotaxin, bronchial hyperreactivity, eosinophilia, goblet cell hyperplasia and $\mathrm{TH} 2$ cytokine response) was evident in the local draining lymph nodes/airways of mice after intratracheal applications of recombinant SplD without adjuvant [101, 115]. SplD-specific IgE was also found in human
B Function and mode of action of Aur proteases

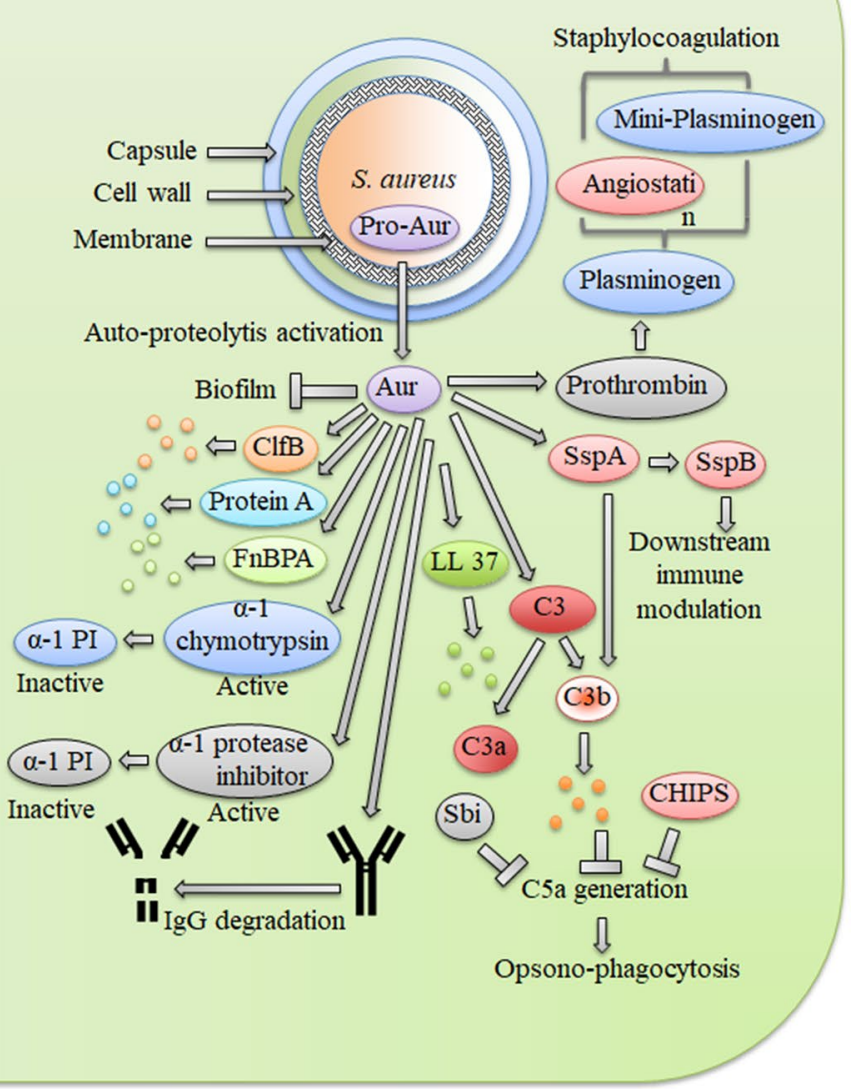

Role of Aur in host immune regulation. Immature Aur (Pro-Aur) is secreted out of pathogen and processed through autocatlytic activation. Active enzyme then activates SspA and SspB. Aur cleaves C3 into $\mathrm{C} 3 \mathrm{a}$ and $\mathrm{C} 3 \mathrm{~b}$. Then Aur inhibits $\mathrm{C} 3 \mathrm{~b}$ deposition and $\mathrm{C} 5 \mathrm{a}$ generation, and thus inhibits opsono-phagocytosis. CHIPS (chemotaxis inhibitory protein of $S$. aureus) and Sbi also assist in C5a inhibition. Aur also cleaves IgG, FnBPA (Fibronectin protein A), Protein A, ClfB (Clumping factor B), $\alpha$-1-protease inhibitor and $\alpha-1$ antichymotrypsin. Aur activates prothrombin to induce staphylocoagulation

airway mucosa. Eosinophilia and increase in TH2 cytokine production is IL-33 dependent, while IgE production and goblet cell metaplasia are independent of this pathway [115]. Cleavage and maturation of IL-33 does not depend on SplD but rather on endogenous neutrophil elastase or cathepsin G from neutrophils, which are released during bacterial infections [116].

SplD-mediated allergic response is also characterized by production of IL-1a, IL-25, TSLP (thymic stromal lymphopoietin that is a pleiotrophic cytokine involved in pathogenesis of asthma) and GM-CSF (Granulocyte-macrophage colony-stimulating factor secreted by immune cells) but it 
does not cause degranulation of mast cells (Fig. 3a). Additionally, ILC2s and basophils are also produced [117]. SplD treatment also promotes migration of Dendritic cells (DCs that help in antigen processing and immune response initiation) to lung and local lymph nodes where they probably mediate priming of $\mathrm{TH} 2$ cell differentiation from naive $\mathrm{T}$ cells (Fig. 3a) [115, 118]. DC maturation is mediated by IL-33 while population of local T- and B-cell is not affected by IL-33 [119, 120]. SplD also induces the secretion of OVA-specific IgE antibodies when given in combination with OVA. OVA is an inert protein but when $S$. aureus enterotoxin B (a superantigen) is present it can activate $\mathrm{TH} 2$ response and bronchial hyperreactivity [121, 122]. This response is independent of the IL-1 receptor pathway and mediated by activation of inflammatory DCs and polyclonal T cells [123].

According to Hammad et al. [124] SplD mediated allergic responses are independent of TLR4 (Toll-like receptor 4-a transmembrane protein that also activates NF- $\mathrm{kB}$ and immune responses in presence of allergens) [125]. Additionally, SplD did not directly activate TLR2 in-vitro. sST2 (soluble suppression of tumorigenicity 2) inhibit production of PAR2 + cells (that act independently of TLR4) in the lungs after SplD treatment (Fig. 3a) [126]. PARs are cell surface Protease-Activated Receptors that recognizes allergens and play a key role in TH2 cytokine response [127, 128]. They lead to cleavage of intercellular epithelial tight junctions, CXCR1 present on neutrophil surfaceand CD23 as well as CD25 receptors present on immune cells thereby enhancing allergy development $[129,130]$.

\section{SpIC, SplE and SplF}

SplC shows structural homology to SspA and ETs [131]. It shows restricted substrate specificity and remains inactive in absence of a substrate. Because of an unusual conformation of the adjacent flexible occulding loop its active triad (His, Asp, Ser) remains blocked. In this case, the catalytic His residue is rotated outside the catalytic cleft due to steric conflict with the adjoining Gly-Gly residues. It is postulated that catalytic activity is retained when a substrate induces conformational switch in the occluding loop developing an oxyanion hole [92]. SplC contains a trypsin like fold with two perpendicular $\beta$-barrels interrupted by a short helix and a longer helix at the $\mathrm{C}$ terminus. It also has a hydrophobic S1 substrate-binding subsite that can capture non-polar sidechain of the substrate [92].

SplE shows unique substrate specificity because of the unusual or distorted organization (sterically restricts unspecific substrate access and oxyanion hole formation) of its $\mathrm{S} 1$ subsite. It also shows $\mathrm{P} 1$ subsite substrate specificity, which is not found in other spl proteases. It prefers (Y/F/W)L-(H/Q) $\downarrow$ consensus motif in its substrates. SplE contains chymotrypsin-like fold consisting of two $\mathrm{b}$ barrel domains [132].

SplF is found in human in nasal polyps and airway mucosa released from intramucosal bacteria during allergic responses. In asthma it shows similar inflammatory response to that of SplD such as allergic sensitization and eosinophilia [93, 115]. SplD and SplF share 94.6\% similarity, therefore, speculated to share similar properties [90].

\section{Metalloproteinase}

\section{Aureolysin (Aur)}

They belong to the M4 family of metallopeptidases (contains one zinc ion for enzyme activity and four calcium ions for structural stability). It contains 301 amino acids that folds into a $\beta$-pleated $\mathrm{N}$-terminal domain and an $\alpha$-helical C-terminal domain [133]. Aur is produced as a zymogen that contains an N-terminal fungalysin-thermolysinpropeptide (FTP) domain. During secretion and passage across the outer membrane rapid autocatalytic processing of FTP occurs rendering Aurproteolytic activity (Fig. 3b) [134]. Then Aur initiates staphylococcal proteolyticcascade, which involve activation of serine protease SspA, and cysteine protease SspB (Fig. 3b) [53]. Aur is reported to actively inhibit phagocytosis and killing of bacteria by neutrophils through repression of the classical as well as alternative pathways of complement system [51]. Aur mimics $\mathrm{C} 3$ convertase and cleaves $\mathrm{C} 3$ (central component of the complement system) in the $\alpha$-chain yielding C3a and $\mathrm{C} 3 \mathrm{~b}$ as shown in Fig. 3b [135]. C3b opsonizes bacteria; activate potent anaphylatoxin $\mathrm{C} 5 \mathrm{a}$ (attracts and activates phagocytes) and phagocytosis. Aur inhibits $\mathrm{C} 3 \mathrm{~b}$ deposition by working in collaboration with host factors $\mathrm{H}$ and I. Therefore, it also inhibits C5a generation and neutrophil chemotaxis. Another S. aureus secreted protein CHIPS (chemotaxis inhibitory protein of $S$. aureus) along with Aur helps in inhibition of neutrophil chemotaxis by impairing function of the $\mathrm{C} 5 \mathrm{a}$ and formylated peptide receptors [136, 137]. Inhibition of C3 induced immune response by Aur is also assisted by $S$. aureus Sbi [63, 64]. Aur may act along side SspA to mediate these complement inhibitor responses as well as cleavage of staphylococcal surface-associated proteins such as fibronectin-binding protein and Protein A [40, 135]. It also regulates and cleaves fibrinogen-binding protein clumping factor B (ClfB, Fig. 3b). ClfB is surface-associated protein that is covalently attached to the cell wall and mediate adherence of bacteria to immobilized fibrinogen as well as to the blood clots. Proper reason of this cleavage is unknown but it is hypothesized that cleavage of ClfB may induce detachment of bacterial cells from colonized sites and assist in the spread of infection within the host [138]. Aur is also 
reported to inhibit biofilm formation, which is assisted by other proteases such as ScpA, SspA and SspB [139, 140].

Aur affects immune response development by regulating the degradation of Igs, cathelicidin-derived antimicrobial peptide LL-37, serpin-type plasma protease inhibitors $\alpha 1$-proteinase (endogenous protease inhibitor that regulates neutrophil serine protease elastase) as well as $\alpha 1$-antichymotrypsin (Fig. 3b) [50, 84]. Cleavage of antimicrobial peptides by Aur might protect staphylococci inside the phagocytes [141, 142]. It also promotes bacterial escape from the host immune system by converting plasminogen into angiostatin and mini-plasminogen (miniplasminogen activates urokinase-type plasminogen activator-uPA to hydrolyse fibrin). Aur also targets the activation of prothrombin (that promotes staphylocoagulation) and fibrinolytic system leading to bacterial spread and invasion as shown in Fig. 3b [143]. EDTA that acts as ion chelator is reported to inhibit Aur activity [56]. Thrombin-derived TCPs (C-terminal peptides) acts as HDPs (host defense peptides) that interact with bacterial lipopolysaccharide and provide both anti-inflammatory and anti-microbial activities invitro, with therapeutic potential against infection and septic shock in-vivo. Proteolytic signatures or peptide biomarkers for Aur have been studied which could be explored for the development of novel therapeutics [144].

\section{Autolysins/adhesins (LytM)}

These peptidoglycan hydrolases (similar lysostaphin-like metalloproteases or endopeptidase) are secreted from $S$. aureus that is involved in various responses such as bacterial cell wall metabolism, cell division, daughter cell separation, growth, antibiotic mediated cell lysis and pathogenicity [145]. Autolysin Aaa is involved in the adherence of $S$. aureus to surface-adsorbed extracellular matrix proteins fibrinogen and fibronectin. It could not lyse pentaglycine but when fused with catalytic and cell wall binding domains (CWBDs) of lysostaphin (a zinc-dependent $27 \mathrm{kDa}$ glycyl glycine M23 family metalloendopeptidases from $S$. simulans that cleaves the $\mathrm{N}$-acylmuramoyl-Ala bond between the cell wall peptidoglycan and the crosslinking peptide), the chimeric protein could effectively display anti-staphylococcal activity [146-148]. CWBD mediates transport of enzyme to the bacterial outer surface, assisting in the direct contact of catalytic domain with PG substrates. Therefore, LytM can also be targeted for the development of new antibacterial therapeutics. These possess similar active site and core folding motif but have highly divergent folds [149]. It is also zinc-dependent enzyme with $\mathrm{N}$ - and C-terminal. LytM synthesis has been shown to be elevated in vancomycin-resistant $S$. aureus [150, 151]. In $S$. aureus its expression is negatively modulated by RAT that is a regulator of autolytic activity [152]. Series of (phenylureido) piperidinyl benzamides have been identified as the prospective inhibitors of Autolysin $\mathrm{E}$ [153]. Atl (Major Autolysin/peptidoglycan hydrolase with amidase and glucosaminidase domains) facilitate interaction of $S$. aureus to various host cellular components during infection such as fibronectin, gelatin, thrombospondin 1 , vitronectin and heparin [154]. Atl also induces platelet activation and aggregation in whole blood [155]. Targocil is a novel bacteriostatic inhibitor that blocks growth of various $S$. aureus strains by impairing Atl translocation across $S$. aureus membrane. It targets the TarG subunit of the TarGH (WTA-wall teichoic acid translocase) that transports WTA across the membrane to the wall. WTA is essential for maintaining cell surface integrity, growth and tissue colonization during infection [156].

sa0205

This enzyme from $S$. aureus also carries lysostaphin-type endopeptidase catalytic domain [157]. It is 192 amino acid long and possesses a 25 amino acid N-terminal signal sequence that acts as a membrane anchor followed by a short 23 amino acid linker with unknown function [146, 158]. Linker region in LytM and lysostaphin is quite long (159 and 227 amino acids respectively). For catalytic activity it requires a single zinc ion but high concentration of zinc is shown to inhibit enzyme activity. It is regulated by vancomycin-resistance associated sensor/regulator (VraSR) two-component system that modulates synthesis of cell wall positively. Therefore, it is involved in resistance to vancomycin bacterial cell wall synthesis [159].

\section{Types of S. aureus factors that modulate host proteases for disease development}

For the induction of virulence and pathogenicity, in addition to proteases various other factors are secreted by $S$. aureus that activate or inhibit immune responsive host proteases.

\section{Coagulase (Coa)}

The outstanding pathogenic potential of $S$. aureus is attributed to the capacity of bacteria to evade immune responses. One of the mechanisms is the development of a pseudocapsule in the abscesses and the lesion area that protect the bacteria from host immune cells. This is facilitated by clotting factors Coa, a polypeptide that binds and initiates nonproteolytic activation of prothrombin [160]. Coa possesses two $\mathrm{N}$ terminal $\alpha$-helical domains (D1 and D2), linker region and a C-terminal end of tandem repeats [161, 162]. D1 and $\mathrm{D} 2$ of Coa (acts as a cofactor) interact with the C-terminal $\beta$-chain of prothrombin inducing a conformational change and forming a functional active site [163]. This alteration 
in conformation is brought by the insertion of $\mathrm{Ile}^{1}-\mathrm{Val}^{2}$ of the D1-D2 domain into $\mathrm{Ile}^{16}$ pocket of prothrombin. The resulting complex is known as staphylothrombin that induce conversion of fibrinogen to fibrin and fibrinopeptides as shown in Fig. 4a [164]. The formation of fibrin networks promotes clotting of blood or plasma. It also defends $S$. aureus phagocytic as well as neutrophil clearance and facilitates spread of pathogenesis in blood stream $[165,166]$. Coa is also regulated by sar/agr locus. Coa mediated activation of prothrombin also promotes direct cleavage of complement component $\mathrm{C} 3$ and its activation fragments (Fig. 4a). In addition, thrombin can cleave $\mathrm{C} 5$ into $\mathrm{C} 5 \mathrm{a}$ independent of C3. Dabigatranandargatroban are reported to be potent inhibitors of staphylothrombin $[167,168]$.

\section{vonWillebrand factor binding protein (vWbp)}

vWbp (a large multifunctional glycoprotein) is another $S$. aureus sectreted protein that facilitates blood clumping. It is $270 \mathrm{kDa}$ in size and exists as homodimer or multimer. It possesses a positively charged $\mathrm{N}$-terminal domain (homologous to D1 and D2 domain of Coa), a unique hydrophobic vWF motif (interacts with the A1-domain of VWF) and a more polar fibrinogen binding site $[165,169]$. Similar to Coa it also activates prothrombin to cleave fibrinogen into fibrin. Coa and $\mathrm{vWbp}$ works along with clumping factor $\mathrm{A}$ (ClfA) to form fibrin cables and induce coagulation cascade as shown in Fig. 4a [170, 171]. It leads to the formation of abscesses, lethal sepsis and bacterial spread in host tissues. vWbp also interacts with fibronectinas well as factor XIII and triggers non-proteolytic activation of FXIII (helps in fibrin crosslinking during blood coagulation) zymogen invitro [172]. vWbp is also associated with endovascular infections such as endocarditis. VWF in the inflamed or damaged endothelium bridges to the secreted $\mathrm{vWbp}$ which in turn interacts with SrtA (Sortase A)-dependent staphylococcal surface protein ClfA (Fig. 4a). S. aureus SrtA is a transpeptidase that interacts with MSCRAMMs (microbial surface components recognizing adhesive matrix molecules) such as ClfA with the C-terminal cell wall sorting signal containing a Leu-Pro-X-Thr-Gly (LPXTG) motif. This complex helps bacterial cells to overcome shear forces of flowing blood and anchoring themselves in the vascular endothelium. It promotes bacterial adherence to the host cell and extracellular matrix [173, 174]. Direct thrombin inhibitors are effective against $\mathrm{vWbp}$ mediated agglutination cascade [175].

\section{a-toxin}

One of the main cytotoxic agents secreted by S. aureus is the $\alpha$-toxin or $\alpha$-hemolysin (Hla). It belongs to the pore forming beta-barrel toxin family characterized by seven heptameric monomers that forms a pore in the cell membrane [176].
The mature extracellular protein is $33 \mathrm{kDa}[177,178]$. It forms a membrane-inserted heptamer by self-assembly to promote host cell lysis and death. Naturally occurring catechin epigallocatechin gallate is reported to impair the haemolytic activity of $\alpha$-toxin by blocking heptamer self-assembly [179]. It is regulated at transcriptional and translational level by two long non-coding RNAs, SSR42 (effector of $R s p$-repressor of surface proteins regulator) and RNAIIII (agr regulator) [180]. It causes cellular death by necrosis, apoptosis or pyroptosis [181]. In alveolar epithelial cells it interacts with receptor ADAM10 (A Disintegrin and metalloproteinase domain-containing protein 10) that promotes activity of ADAM10 (also known as CDw156 or CD156c) metalloprotease (Fig. 4b) [182]. It has a disintigrin and cysteine-rich domain that is distinct from the active site plays a critical role in the regulation of protease activity and substrate specificity [183]. Their primary function is to cleave membrane proteins such as TNF-alpha and E-cadherin at the cellular surface (Fig. 4b) $[184,185]$. TNFalpha is a cytokine involved in systemic inflammation and produced by immune cells such as macrophages and CD4+ lymphocytes. E-cadherin (calcium-dependent adhesion) is essential for formation of adherens junctions to bind cells with each other [186]. Cleavage of these proteins leads to disruption of epithelial barrier function, increased staphylococcal invasion and disease development [9]. $\alpha$-toxin causes high tissue toxicity and loss of skin epithelial integrity in human skin model [187]. It is also reported to cause pulmonary infections of cystic fibrosis in mice and rapid chondrocyte death in bovine cartilage during septic arthritis $[188,189]$. $\alpha$-toxin also leads to platelet aggregation (at first prevents $S$. aureus but later damages thrombosis in liver) and multi-organ dysfunction during sepsis. Administration of $\alpha$-toxin neutralizing antibody (MEDI4893*) did not affect the initial and beneficial platelet recruitment but impaired platelet aggregation and subsequent liver damagein mice [190, 191]. Another human anti- $\alpha$-toxin IgG1 monoclonal antibody is MEDI4893 (Suvratoxumab) that impairs $\alpha$-toxin lytic activity in-vitro and $S$. aureus fitness [192]. Cerulenin (inhibits fatty acid and steroid biosynthesis) is reported to inhibit secretion of $S$. aureus $\alpha$-toxin [193]. Flavonoid Lysionotin (5,7-dihydroxy-4',6,8-methoxyflavone) derived from Lysionotus pauciflorus is reported to protect human epithelial cells by inhibiting $\alpha$-toxin expression. Lysionotin can also protect mice from pneumonia caused by $S$. aureus [194]. AP-1 family mammalian transcriptional regulator c-Jun proto-oncoprotein is phosphorylated and activated by $\alpha$-toxin. Once activated c-Jun protects Lung Epithelial Cells from $\alpha$-toxin [195]. It is reported that sub-inhibitory concentration of Mupirocin (pseudomonic acid A, competitive inhibitor of isoleucyl-tRNA synthetase) impairs $\alpha$-toxin by downregulating agr, saeRS and sarA [196]. $\alpha$-toxin is inhibited by another flavonoid Eriodictyol [197]. In recent 


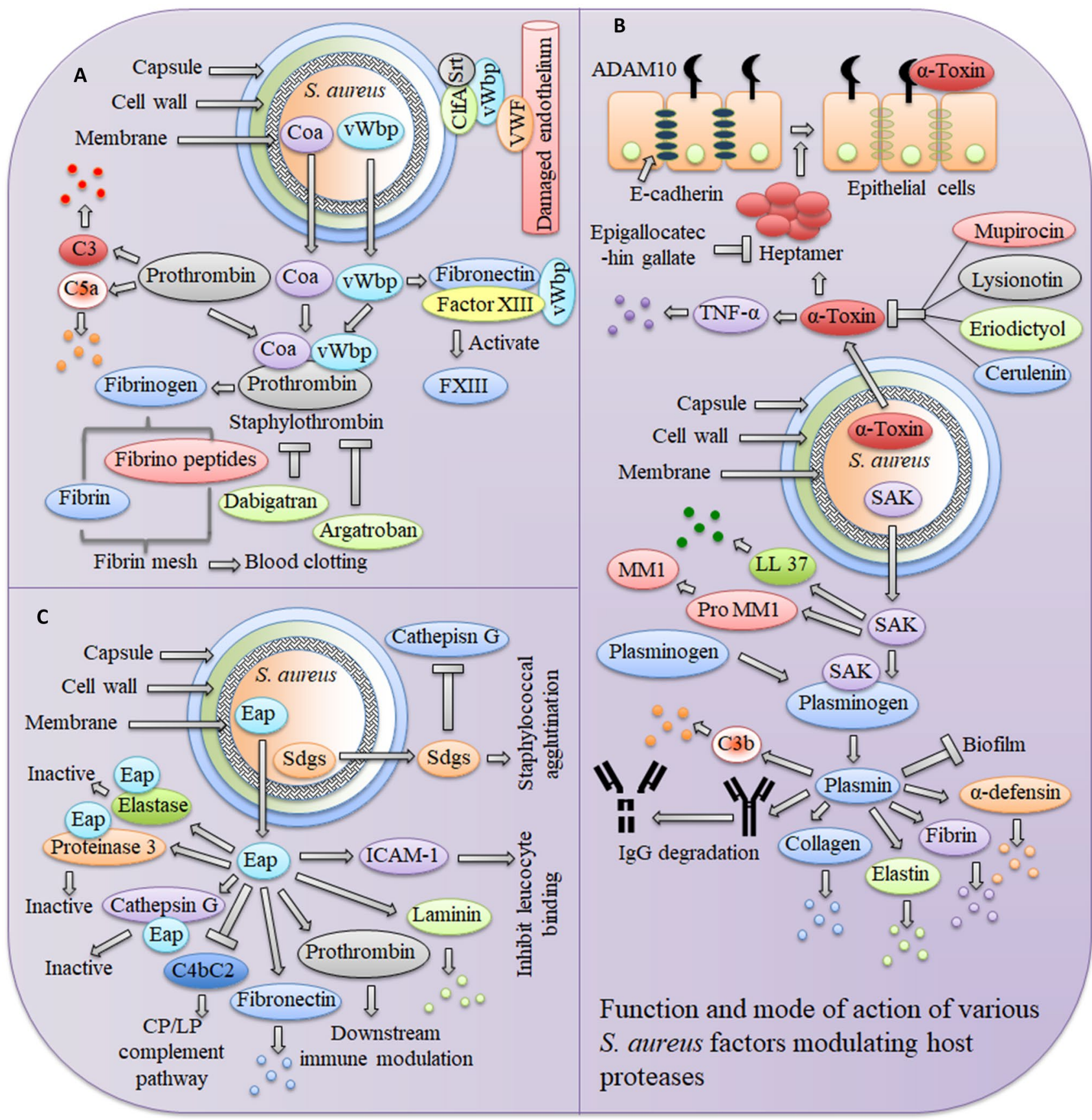

Fig. 4 Function and mode of action of various $S$. aureus viulence factors. a Role of vWbp and Coa in host immune regulation. Coa and vWbp induce coagulation cascade by interacting with prothrombin which cleave fibrinogen into fibrin and fibrino peptides. Coa mediated activation of prothrombin also promotes direct cleavage of $\mathrm{C} 3$. In addition, thrombin can cleave C5 into C5a independent of C3. Dabigatran and argatroban inhibit interaction of prothrombin with Coa and vWbp. vWbp also promotes association of bacteria with the damaged vascular tissue by forming a complex with VWF (von Willebrand Factor), ClfA and SrtA (Sortase A). vWbp also activates enzyme FXIII by interacting with fibronectin and Factor XIII. b Role of $\alpha$-Toxin and SAK in host immune regulation. $\alpha$-toxin forms hepatmer to promote host cell lysis which is inhibited by epigallocatechin gallate. It interacts with ADAM10 (A Disintegrin and metalloprotein- ase domain-containing protein 10) and cleaves membrane proteins such as TNF-alpha and E-cadherin. $\alpha$-toxin is inhibited by Mupirocin, Lysionotin, Eriodictyol and Cerulenin. SAK interacts with plasminogen and activates plasmin which degrades IgG, C3b, elastin, collagen, fibrin, $\alpha$-defensin and antimicrobial peptide LL-37. SAK also inhibits biofilm formation and activates matrix metalloprotease 1. c Role of Eap and Sdgs in host immune regulation. Eap inhibits Elastase C, Proteinase 3 and Cathepisn G. It also inhibits formation of $\mathrm{C} 4 \mathrm{bC} 2$. Eap interacts and regulates fibronectin, fibrinogen, laminin and prothrombin. Eap also interacts with ICAM-1 (intercellular adhesion molecule 1) that leads to inhibition of leukocytes binding to endothelial cells. Sdgs inhbit Cathepisn G activity and assist in staphylocoagulation 
study biomimetic toxin nanosponges (behaves as toxin decoy and absorb hemolytic toxin) have been developed by coating membranes of human red blood cells onto polymeric nanoparticles to neutralize $\alpha$-toxin [198].

\section{Staphylokinase (SAK)}

It is a $15.5 \mathrm{kDa}$ bacteriophage encoded protein it is positively regulated by agrand negatively by sarA locus [199, 200]. 3D crystallography structure shows a central $\alpha$-helix, a five-strand $\beta$-sheet and the connecting loops [201]. SAK is a thrombolytic agent and it interacts with plasminogen by its $\alpha$-helix domain leading to its non-proteolytic activation (Fig. 4b) [202, 203]. Dimerization of staphylokinase-plasminogen alters conformation of plasminogen and converts it to broad-spectrumproteolytic enzyme plasmin (Fig. 4b) [200, 204]. Plasmin initiates bacterial penetration into the surrounding tissues and fibrin specific thrombolysis of major opsonins such as $\operatorname{IgG}$ as well as C3b in human plasma (Fig. 4b) [205]. Staphylococcal bound plasmin also cleaves zymogen of one of the major interstitial collagenase pro-matrix metalloprotease 1 into active matrix metalloprotease 1 (enhances the lysing effects of plasmin) [206]. SAKplasminogen complex also hampers biofilm formation [207]. C-terminal of SAK also interacts with $\alpha$-Defensins (short cationic $\beta$-sheet bactericidal human neutrophil peptides) and promotes staphylococcal resistance to host innate immunity (Fig. 4b) [208, 209]. It also interacts and inhibits another $18 \mathrm{kDa}$ antimicrobial peptide LL-37 (also known as CAP-18 for cathelicidin antimicrobial peptide) found in immune cells such as macrophages, leukocytes and keratinocytes (Fig. 4b) $[9,210]$.

\section{Extracellular adherence protein (Eap)}

Eap consist of 4-6 tandem repeats of Eap domain that possesses a core fold of an $\alpha$-helix lying diagonally across a five-stranded, mixed $\beta$-sheet [211]. It belongs to SERAM (secretable expanded repertoire adhesive molecules) family proteins. Eap and its two structural homologues EapH1 and EapH2 impairs the adherence of neutrophils to nonstimulated and TNF-alpha stimulated endothelial cells thereby preventing release of neutrophil serine proteases. It also inhibits extracellular killing of bacteria and transendothelial migration of neutrophils to reduce inflammation responses. It directly interferes with the activity of neutrophil serine proteases such as elastase (cleaves elastin determines the mechanical properties of connective tissue), proteinase 3 (critically associated with proteolytic generation of antimicrobial peptides) and cathepsin $\mathrm{G}$ (plays a critical part in elimination of intracellular bacteria and break down of tissues at the inflammatory sites) by occluding their catalytic cleft (Fig. 4c) [212, 213]. Eap inhibits classical and lectin pathways of complement. It prevents interaction of $\mathrm{C} 2$ from $\mathrm{C} 4 \mathrm{~b}$ thus disrupts formation of $\mathrm{C} 4 \mathrm{bC} 2$ (CP/LP C3 proconvertase). It does not allow the formation of $\mathrm{C} 3 \mathrm{~b}$, and thus prevent $S$. aureus opsonophagocytosis and killing by neutrophils [214]. Eap also interacts with plasma proteins such as fibronectin, fibrinogen, laminin and prothrombin (Fig. 4c) $[9,215]$. Its interaction with pro-inflammatory mammalian surface adhesion ICAM-1 (intercellular adhesion molecule 1) leads to inhibition of leukocytes binding to activated endothelial cells as well as movement of leukocytes from bloodstream to the infection site (Fig. 4c) [216, 217]. Eap interacts with platelets and leads to its activation and aggregation in whole blood [155]. Eap is also described as an intrinsic DNA-binding protein that leads to DNA aggregation and thereby inhibit anti-microbial defense response of host. Eap also reduces NETs (neutrophil extracellular traps composed of DNA-histone scaffolds) formation [218]. It also interferes with growth factor-stimulated activation of the MAPK (mitogen-activated protein kinase) pathway that is known to be responsible for cell shape modulation. It leads to altered morphology and adhesive properties of keratinocytes. It impaires proliferation and migration capacities of keratinocytes and inhibits re-epithelialization process during wounding [218].

\section{Serine aspartate glycosyltransferases (SdgA and SdgB)}

Sdgs are involved in GlcNAc modification ( $N$-Acetylglucosaminylation) of pathogenesis responsive serine-aspartate (SD) repeat proteins such as ClfA. They directly interact and covalently link GlcNAc moieties to the SDR-domain. As shown in Fig. 4c, it inhibits proteolysis of SD repeat proteins by human neutrophil-derived cathepsin G (serine proteases of the chymotrypsin family involved in elimination of intracellular pathogens). This mediates immunogenicity and inhibits degradation of virulence-associated cell wall proteins [219, 220]. SdgB also contribute to staphylococcal agglutination with fibrin fibrils in human plasma [221].

\section{Extracellular fibrinogen binding protein (Efb)}

Staphylococcus aureus $\mathrm{Efb}$ is a $15.8 \mathrm{kDa}$ potent virulence factor as it inhibits bacterial opsonization and phagocytosis. $\mathrm{Efb}$ mimics as an allosteric inhibitor, blocks binding of $\mathrm{C} 3 \mathrm{~b}$ with complement factor $\mathrm{B}$ and the generation of active $\mathrm{C} 3$ convertase [222]. It interacts with $\mathrm{C} 3 \mathrm{~b}$ by its $\mathrm{C}$-terminus and with fibrinogen (A $\alpha$-chain of the $\mathrm{D}$ fragment) by its $\mathrm{N}$-terminus generating a trimolecular complex that impairs the host resistance (Fig. 5a) [223]. Fibrinogen deposition on the bacterial surface induces the formation of protective pseudocapsule (fibrin network) around bacteria with the help of prothrombin. The fibrinogen-binding domain is similar 
to that of coa [224]. N-terminal domain of Efb also induces platelet binding of fibrinogen and impairs platelet activation. This results in inhibition of platelet-monocyte and platelet-granulocyte complex formation involved in innate immune response [225]. It also inhibits Maps (MHC class II analog proteins involved in $\mathrm{T}$ cell responses and neutrophil recruitment) and CHIPS that interacts with $\mathrm{C} 5 \mathrm{a}-$ as well as formylated peptide receptors to mediate early inflammatory response (Fig. 5a) [136, 137, 226].

\section{Collagen adhesion protein (Cna)}

Cna is a prototype cell surface adhesion protein involved in pathogenesis and host immune evasion [227]. This multimodular cell wall anchored protein belongs to MSCRAMM (microbial surface component recognizing adhesive matrix molecules) family of adhesins [228]. Cna possesses an N-terminal signal peptide, a non-repetitive A region with N1, N2 and N3 domains; tandem B repeats and a cell wall-anchoring

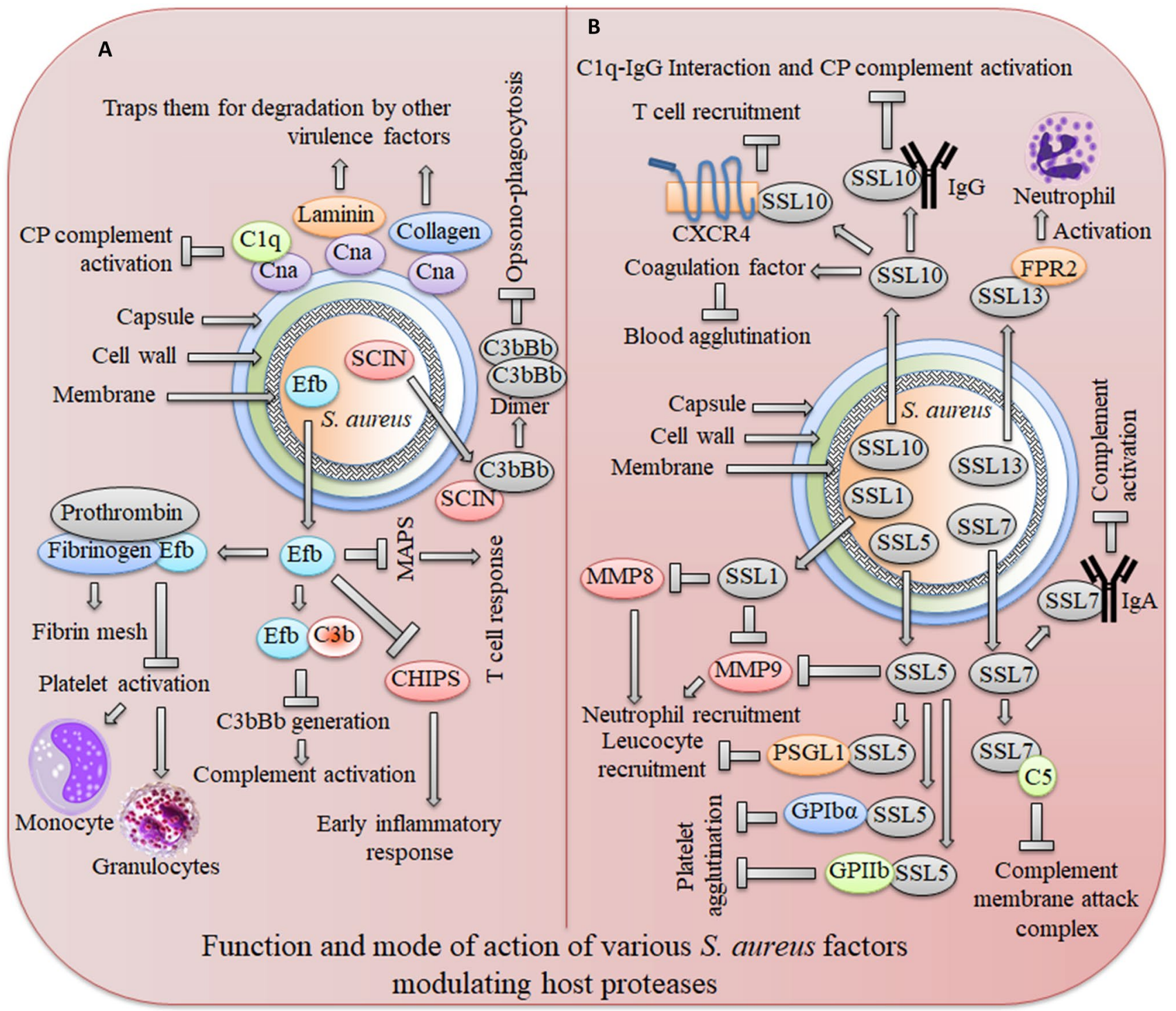

Fig. 5 Function and mode of action of various $S$. aureus viulence factors. a Role of Efb, SCIN and Cna in host immune regulation. $\mathrm{Efb}$ inhibits C3 convertase generation. Efb interacts with fibrinogen to form protective pseudocapsule (fibrin mesh) for bacteria and impair platelet-monocyte/granulocyte complex formation. Eap also inhibit Maps (MHC class II analog protein) and CHIPS to suppress immune responses. Can interacts with collagen, laminin and $\mathrm{C} 1 \mathrm{q}$ to trap them for degradation by other virulence factors. SCIN leads to dimerization of $\mathrm{C} 3 \mathrm{bBb}(\mathrm{C} 3$ convertase) and inhibits opsonophago- cytosis. b Role of SSLs in host immune regulation. SSL1 and SSL5 inhibit matrix metalloproteinase MMP8/9 and neutrophil recruitment. SSL5 also interacts with PSGL-1 (P-selectin glycoprotein ligand-1) to inhibit leucocyte recruitment and GPIb $\alpha /$ GPIIb receptors to inhibit platelet agglutination. SSL7 interacts with C5 to inhibit complement membrane attack complex formation and also targets IgA to block complement activation. On the other hand, SSL13 acts as a positive host immune regulator and helps recruit neutrolphils by interacting with FPR2 (formyl-peptide receptor 2) 
region containing an LPXTG-domain; a transmembrane segment and a short positively charged cytoplasmic tail. Cna interacts with complement protein $\mathrm{C} 1 \mathrm{q}$ (possessing six collagen-like triple helix domains) and inhibit the classical pathway (CP) of complement fixation (Fig. 5a) [229]. This is mediated by inhibition of interaction of $\mathrm{C} 1 \mathrm{q}$ with $\mathrm{C} 1 \mathrm{r}$ and $\mathrm{C} 1$ proteases. This interaction was supposed to induce self-activation of $\mathrm{C} 1 \mathrm{r}$ that process proenzyme $\mathrm{C} 1$ into an active serine protease leading to cleavage of $\mathrm{C} 4$ and $\mathrm{C} 2$. The heterotetramer complex C1r2C1s2 then activates CP [230].

As shown in Fig. 5a Cna interacts with ligand (collagen) by collagen hug (multistep binding mechanism in which N-terminal N1-N2 of A domain of Cna wrap around collagen triple-helical rod and B domain provides stability to the interaction). It also interacts with extracellular matrix protein Lam (laminin, an important component of the basement membrane). Both C1q and Lam binding is weak as well as different from collagen hug interaction and can be efficiently inhibited by monoclonal antibodies directed against the collagen-binding domain of Cna [231].

\section{Staphylococcal complement inhibitor (SCIN)}

SCIN is another complement-evasion molecule that inhibits $\mathrm{C} 3$ convertase (central component of complement pathways). It is a $9.8 \mathrm{kDa}$ protein having triple $\alpha$-helical bundle structure connected by two short loops [232]. SCIN is regulated by $S$. aureus genetic cluster SaPI5 (S. aureus pathogenicity island 5). It leads to dimerization of $\mathrm{C} 3$ convertase ( $\mathrm{C} 3 \mathrm{bBb}$ ), blocks $\mathrm{C} 3 \mathrm{~b}$ deposition, inhibits chemotaxis as well as phagocytosis and impairs $\mathrm{C} 5 \mathrm{a}$ generation by $\mathrm{C} 4 \mathrm{~b} 2 \mathrm{aC} 3 \mathrm{~b}$ (Fig. 5a) [233]. Dimeric enzyme inhibits interaction with complement receptor 1 and the complement receptor of the Ig superfamily [234]. It is produced extensively during the early stages of biofilm formation. Human monoclonal antibody humAb 6D4 is reported to specifically interact and inhibit SCIN [235].

\section{Superantigen-like proteins (SSLs)}

S. aureus genomic pathogenicity island $\mathrm{vSa} \alpha$ encodes 14 SSLs that share structural homology (not functional) with the classical superantigens [236, 237]. They are characterized by the presence of an N-terminal oligonucleotide/ oligosaccharide-binding $(\mathrm{OB})$ fold linked to the $\mathrm{C}$-terminal $\beta$-grasp domain and lack functional T-cell receptor binding domain [238].

SSL1 is a broad range matrix metalloproteinase (MMP, degrades extracellular matrix and modulate inflammation) inhibitor. It inhibits MMP8 (neutrophil collagenase) and MMP9 (neutrophil gelatinase B). It leads to impairment of neutrophils migration through collagen and MMP-mediated cleavage and potentiation of IL-8 (Fig. 5b). Thus, SSL1 blocks activation, chemotaxis and migration of neutrophil [239]. S. aureus escapes TLR2 signaling (Toll-like receptors recognize bacterial lipoproteins and play an important role in the host defense responses) by secreting SSL3 and SSL4 [240]. SSL5 is also reported to interact and inhibit activity of MMP8 as well as MMP9 and thereby inhibit neutrophil transmigration through Matrigel basement membrane (Fig. 5b) [241, 242]. SSL5 is reported to interact with neutrophil surface receptor CD162 [243]. SSL5 also interacts with PSGL-1 (P-selectin glycoprotein ligand-1) that is found on leukocytes and mediates movement of leukocyte on vascular endothelium (Fig. 5b) [244]. SSL5 impairs platelet agglutination by interacting with GPIb $\alpha$ and GPIIb/IIIa receptors (Fig. 5b) [245]. It antagonizes chemo-attractant by interacting with chemokine and anaphylatoxin receptors [244]. SSL7 is reported to interact with C5, and thus impair formation of the complement membrane attack complex. It also targets IgA to block complement activation [243]. It also has a therapeutic potential and can be used as a C5-targeted drug to control acute complement activation in druginduced immune hemolytic anemia and ABO-incompatible erythrocyte transfusions [246]. SSL10 inhibits blood aggulitination by interfering with the activation of coagulation cascade via binding to the Gla ( $\gamma$-carboxyglutamic acid) domain of coagulation factor but not by directly inhibiting thrombin activity [247]. SSL10 also inhibits recruitment of T cell leukemia via CXCR4 binding (Fig. 5b) [241]. It interacts with human $\mathrm{IgG}$ and impairs binding of $\mathrm{IgG}$ and $\mathrm{C} 1 \mathrm{q}$ as shown in Fig. 5b. It leads to inhibition of CP of complement activation and $\mathrm{Fc} \gamma$ receptor-mediated phagocytosis by neutrophils $[14,248]$. SSL13 does not inhibit host immune processes but help recruit human neutrophils to the site of infection. It behaves as a neutrophil chemoattractant and pathogen alarming molecule. SSL13 activates neutrophils by interacting with FPR2(formyl-peptide receptor 2), induces degranulation and oxidative burst in neutrophils [243].

\section{Identification of virulence factors by Tn-seq}

Tn-seq (Transposon sequencing) or TraDIS (Transposon Directed Insertion Site Sequencing) analysis is a robust method to identify essential, conditionally essential and non-essential genes under different conditions in S. aureus [249]. Transposon libraries are sequenced by high throughput methods to probe the entire $S$. aureus genome with great resolution and sensitivity. In an attempt to identify genes involved in fitness of $S$. aureus in various infected compartments, several fitness and virulence associated genes have been surfaced. It includes SplA, metallo-proteases and host protease modulators such as vWbp and fibrinogen binding protein and $\delta$-hemolysin [249]. Ibberson et al. [250] also has analyzed high throughput $\mathrm{Tn}$-seq data in $S$. aureus 
and found fibrinogen binding protein and $\delta$-hemolysin as the essential gene required for polymicrobial infection. In another Tn-seq study hemolysin has been identified as an essential gene for survival and replication in the resence of nitric oxide [251]. This technique should be employed thoroughly as it identifies potential new targeting opportunities in the entire genome of $S$. aureus for the development of novel therapeutics.

\section{Concluding remarks and future perspectives}

Staphylococcus aureus mediated disease development is becoming a major issue all over the world. Its severe virulence and pathogenicity is attributed to its ability to evade as well as suppress host immunity. This is regulated by various S. aureus secreted proteins known as virulence factors such as proteases and proteins that regulates host proteases. They facilitate entry/invasion through skin, inhibit/evade complement pathway, block/suppress neutrophil protease as well as neutrophil migration, escape/prevent opsonophagocytosis, promotes spread through tissue/blood and assist in disease development/dissemination. This assist in the propagation of TH2-biased diseases, health care- and community-associated infectious diseases causing high morbidity among infected patients. To defeat these detrimental effects of $S$. aureus without compromising the health of patient, new insight is required in the field of host-pathogen interaction. In this review, we add-up the current knowledge and understanding of the crosstalk of host and S. aureus proteases as well as protease regulators. We believe that these integrated networks should be studied/analyzed in detail and future research on the combined regulatory pathway should be undertaken keeping the following points into account:

(a) Functional significance of many proteases and their regulators (from $S$. aureus as well as host) is not fully understood. Therefore, to understand the complete mechanism of $S$. aureus mediated disease development mode of action of novel virulence factors should be studied.

(b) Protease system plays an important role in evasion of immune responses. Therefore, they can be targeted for development of new therapeutic approaches for clinical treatments. But proper clinical trial phases should be employed in the process to avoid host cytotoxicity. Drugs should be used in combination with other compounds to add synergistic effect to the therapies.

(c) Extensive microarray, transcriptomic, Tn-seq and proteomic approaches should be undertaken to analyze the entire network involved in virulence as well as pathogenicity. High throughput screening and identification of novel virulence factors would shed light on the process.

(d) The study should be extended to other Staphylococcal strains and similar bacteria to fully decipher the hostbacterial interaction.

Acknowledgements Authors would like to acknowledge Prof. Ashis Kumar Nandi, JNU, New Delhi, India and Dr. M.P. Darokar CSIRCIMAP, Lucknow, India for their help and support. We would also like to thank Department of Biotechnology (DBT), Ministry of Science \& Technology and DST-SERB, Govt. of India for fellowship.

\section{Compliance with ethical standards}

Conflict of interest All authors declare that they have no conflict of interest.

\section{References}

1. Foster TJ (2005) Immune evasion by staphylococci. Nat Rev Microbiol 12:948-958

2. Singh V, Pal A, Darokar MP (2015) A polyphenolic flavonoid glabridin: Oxidative stress response in multidrug-resistant Staphylococcus aureus. Free Radic Biol Med 87:48-57

3. Lowy FD (1998) Staphylococcus aureus infections. N Engl J Med 339:520-532

4. David MZ, Daum RS (2010) Community-associated methicillin-resistant Staphylococcus aureus: epidemiology and clinical consequences of an emerging epidemic. Clin Microbiol Rev 23:616-687

5. Sachse F, Becker K, von Eiff C, Metze D, Rudack C (2010) Staphylococcus aureus invades the epithelium in nasal polyposis and induces IL-6 in nasal epithelial cells in vitro. Allergy 65:1430-1437

6. Kobayashi T, Glatz M, Horiuchi K, Kawasaki H, Akiyama H, Kaplan DH, Kong HH, Amagai M, Nagao K (2015) Dysbiosis and Staphylococcus aureus colonization drives inflammation in atopic dermatitis. Immunity 42:756-766

7. Tomassen P, Vandeplas G, Van Zele T, Cardell LO, Arebro J, Olze H, Förster-Ruhrmann U, Kowalski ML, Olszewska-Ziąber A et al (2016) Inflammatory endotypes of chronic rhinosinusitis based on cluster analysis of biomarkers. J Allergy Clin Immunol 137:1449-1456

8. Foster TJ, Geoghegan JA, Ganesh VK, Höök M (2014) Adhesion, invasion and evasion: the many functions of the surface proteins of Staphylococcus aureus. Nat Rev Microbiol 12:49-62

9. Pietrocola G, Nobile G, Rindi S, Speziale P (2017) Staphylococcus aureus manipulates innate immunity through own and host-expressed proteases. Front Cell Infect Microbiol 7:166

10. Nakamura Y, Oscherwitz J, Cease KB, Chan SM, Muñoz-Planillo R, Hasegawa M, Villaruz AE, Cheung GY et al (2013) Staphylococcus $\delta$-toxin induces allergic skin disease by activating mast cells. Nature 503:397-401

11. Bröker BM, Mrochen D, Péton V (2016) The T Cell Response to Staphylococcus. Pathog Aureus 17;5(1)

12. Cho SH, Strickland I, Tomkinson A, Fehringer AP, Gelfand EW, Leung DY (2001) Preferential binding of Staphylococcus aureus to skin sites of Th2-mediated inflammation in a murine model. J Invest Dermatol 116:658-663 
13. Thammavongsa V, Kim HK, Missiakas D, Schneewind O (2015) Staphylococcal manipulation of host immune responses. Nat Rev Microbiol 13:529-543

14. Itoh S, Hamada E, Kamoshida G, Yokoyama R, Takii T, Onozaki K, Tsuji T (2010) Staphylococcal superantigen-like protein 10 (SSL10) binds to human immunoglobulin G (IgG) and inhibits complement activation via the classical pathway. Mol Immunol 47:932-938

15. Koziel J, Potempa J (2013) Protease-armed bacteria in the skin. Cell Tissue Res 351:325-337

16. Travis SM, Anderson NN, Forsyth WR, Espiritu C, Conway BD, Greenberg EP, McCray PB Jr, Lehrer RI, Welsh MJ, Tack BF (2000) Bactericidal activity of mammalian cathelicidinderived peptides. Infect Immun 68:2748-2755

17. Brogden KA, Ackermann M, McCray PB Jr, Tack BF (2003) Antimicrobial peptides in animals and their role in host defences. Int J Antimicrob Agents 22:465-478

18. McAdow M, DeDent AC, Emolo C, Cheng AG, Kreiswirth BN, Missiakas DM, Schneewind O (2012) Coagulases as determinants of protective immune responses against Staphylococcus aureus. Infect Immun 80:3389-3398

19. Kolaczkowska E, Jenne CN, Surewaard BG, Thanabalasuriar A, Lee WY, Sanz MJ, Mowen K, Opdenakker G, Kubes P (2015) Molecular mechanisms of NET formation and degradation revealed by intravital imaging in the liver vasculature. Nat Commun 26:6673

20. Goerke C, Wolz C (2004) Regulatory and genomic plasticity of Staphylococcus aureus during persistent colonization and infection. Int J Med Microbiol 294:195-202

21. Altman DR, Sullivan MJ, Chacko KI, Balasubramanian D, Pak TR, Sause WE, Kumar K, Sebra R, Deikus G, Attie O, Rose H, Lewis M, Fulmer Y, Bashir A, Kasarskis A, Schadt EE, Richardson AR, Torres VJ, Shopsin B, van Bakel H (2018) Genome plasticity of agr-defective Staphylococcus aureus during clinical infection. Infect Immun. https://doi.org/10.1128/ IAI.00331-18 (Epub ahead of print)

22. Ziebandt AK, Becher D, Ohlsen K, Hacker J, Hecker M, Engelmann S (2004) The influence of agr and sigmaB in growth phase dependent regulation of virulence factors in Staphylococcus aureus. Proteomics 4:3034-3047

23. George EA, Muir TW (2007) Molecular mechanisms of agr quorum sensing in virulent staphylococci. Chembiochem 8:847-855

24. Bronner S, Monteil H, Prévost G (2004) Regulation of virulence determinants in Staphylococcus aureus: complexity and applications. FEMS Microbiol Rev 28:183-200

25. Queck SY, Jameson-Lee M, Villaruz AE, Bach TH, Khan BA, Sturdevant DE, Ricklefs SM, Li M, Otto M (2008) RNAIII-independent target gene control by the agr quorum-sensing system: insight into the evolution of virulence regulation in Staphylococcus aureus. Mol Cell 32:150-158

26. Bayer MG, Heinrichs JH, Cheung AL (1996) The molecular architecture of the sar locus in Staphylococcus aureus. J Bacteriol 178:4563-4570

27. Arya R, Princy SA (2013) An insight into pleiotropic regulators Agr and Sar: molecular probes paving the new way for antivirulent therapy. Future Microbiol 8:1339-1353

28. Chien Y, Manna AC, Projan SJ, Cheung AL (1999) SarA, a global regulator of virulence determinants in Staphylococcus aureus, binds to a conserved motif essential for sar-dependent gene regulation. J Biol Chem 274:37169-37176

29. Dunman PM, Murphy E, Haney S, Palacios D, Tucker-Kellogg G, Wu S, Brown EL, Zagursky RJ, Shlaes D, Projan SJ (2001) Transcription profiling-based identification of Staphylococcus aureus genes regulated by the agr and/or sarA loci. J Bacteriol 183:7341-7353
30. Rogasch K, Ruhmling V, Pane-Farre J, Hoper D, Weinberg C, Fuchs S, Schmudde M, Broker BM, Wolz C, Hecker M, Engelmann $S$ (2006) Influence of the two-component system SaeRS on global gene expression in two different Staphylococcus aureus strains. J Bacteriol 188:7742-7758

31. Liu Q, Yeo WS, Bae T (2016) The SaeRS two-component system of Staphylococcus aureus. Genes (Basel) 7(10):81

32. Steinhuber A, Goerke C, Bayer MG, Döring G, Wolz C (2003) Molecular architecture of the regulatory locus sae of Staphylococcus aureus and its impact on the expression of virulence factors. J Bacteriol 185:6278-6286

33. Giraudo AT, Calzolari A, Cataldi AA, Bogni C, Nagel R (1999) The sae locus of Staphylococcus aureus encodes a two-component regulatory system. FEMS Microbiol Lett 177:15-22

34. Geiger T, Goerke C, Mainiero M, Kraus D, Wolz C (2008) The virulence regulator Sae of Staphylococcus aureus: promoter activities and response to phagocytosis-related signals. J Bacteriol 190:3419-3428

35. Novick RP, Jiang D (2003) The staphylococcal saeRS system coordinates environmental signals with agr quorum sensing. Microbiology 149:2709-2717

36. Jonsson IM, Arvidson S, Foster S, Tarkowski A (2004) Sigma factor B and RsbU are required for virulence in Staphylococcus aureus-induced arthritis and sepsis. Infect Immun 72:6106-6111

37. Bischoff M, Entenza JM, Giachino P (2001) Influence of a functional sigB operon on the global regulators sar and agr in Staphylococcus aureus. J Bacteriol 183:5171-5179

38. Sieprawska-Lupa M, Mydel P, Krawczyk K, Wójcik K, Puklo M, Lupa B, Suder P, Silberring J, Reed M, Pohl J, Shafer W, McAleese F, Foster T, Travis J, Potempa J (2004) Degradation of human antimicrobial peptide LL-37 by Staphylococcus aureus-derived proteinases. Antimicrob Agents Chemother 48:4673-4679

39. Smagur J, Guzik K, Bzowska M, Kuzak M, Zarebski M, Kantyka T, Walski M, Gajkowska B, Potempa J (2009) Staphylococcal cysteine protease staphopain B ( $\mathrm{SspB}$ ) induces rapid engulfment of human neutrophils and monocytes by macrophages. Biol Chem 390:361-371

40. Shaw L, Golonka E, Potempa J, Foster SJ (2004) The role and regulation of the extracellular proteases of Staphylococcus aureus. Microbiology 150:217-228

41. Filipek R, Rzychon M, Oleksy A, Gruca M, Dubin A, Potempa J, Bochtler MJ (2003) The Staphostatin-staphopain complex: a forward binding inhibitor in complex with its target cysteine protease. Biol Chem 278:40959-40966

42. Kantyka T, Shaw NL, Potempa J (2015) Staphopain A. Handb Proteolytic Enzymes 2:2150-2157

43. Potempa J, Dubin A, Korzus G, Travis J (1988) Degradation of elastin by a cysteine proteinase from Staphylococcus aureus. J Biol Chem 263:2664-2667

44. Ohbayashi T, Irie A, Murakami Y, Nowak M, Potempa J, Nishimura Y, Shinohara M, Imamura T (2011) Degradation of fibrinogen and collagen by staphopains, cysteine proteases released from Staphylococcus aureus. Microbiology 157:786-792

45. Drapeau GR (1978) Role of metalloprotease in activation of the precursor of staphylococcal protease. J Bacteriol 136:607-613

46. Newsom SW (2008) Ogston's coccus. J Hosp Infect 70:369-372

47. Spaan AN, Henry T, van Rooijen WJM, Perret M, Badiou C, Aerts PC, Kemmink J, de Haas CJC, van Kessel KPM, Vandenesch F, Lina G, van Strijp JAG (2013) The staphylococcal toxin panton-valentine leukocidin targets human C5a receptors. Cell Host Microbe 13:584-594

48. Tsai HH, Frost E, To V, Robinson S, Ffrench-Constant C, Geertman R, Ransohoff RM, Miller RH (2002) The chemokine receptor CXCR2 controls positioning of oligodendrocyte precursors 
in developing spinal cord by arresting their migration. Cell 110:373-383

49. Laarman AJ, Mijnheer G, Mootz JM, van Rooijen WJ, Ruyken M, Malone CL, Heezius EC, Ward R, Milligan G, van Strijp JA, de Haas CJ, Horswill AR, van Kessel KP, Rooijakkers SH (2012) Staphylococcus aureus staphopain A inhibits CXCR2-dependent neutrophil activation and chemotaxis. EMBO J 31:3607-3619

50. Potempa J, Watorek W, Travis J (1986) The inactivation of human plasma alpha 1-proteinase inhibitor by proteinases from Staphylococcus aureus. J Biol Chem 261:14330-14334

51. Jusko M, Potempa J, Kantyka T, Bielecka E, Miller HK, Kalinska M, Dubin G, Garred P, Shaw LN, Blom AM (2014) Staphylococcal proteases aid in evasion of the human complement system. J Innate Immun 6:31-46

52. Dubin G, Krajewski M, Popowicz G, Stec-Niemczyk J, Bochtler M, Potempa J, Dubin A, Holak TA (2003) A novel class of cysteine protease inhibitors: solution structure of staphostatin A from Staphylococcus aureus. Biochemistry 42:13449-13456

53. Massimi I, Park E, Rice K, Muller-Esterl W, Sauder D, McGavin MJ (2002) Identification of a novel maturation mechanism and restricted substrate specificity for the $\mathrm{SspB}$ cysteine protease of Staphylococcus aureus. J Biol Chem 277:41770-41777

54. Quattroni P, Li Y, Lucchesi D, Lucas S, Hood DW, Herrmann M, Gabius HJ, Tang CM, Exley RM (2012) Galectin-3 binds neisseria meningitidis and increases interaction with phagocytic cells. Cell Microbiol 14:1657-1675

55. Farnworth SL, Henderson NC, Mackinnon AC, Atkinson KM, Wilkinson T, Dhaliwal K, Hayashi K, Simpson AJ, Rossi AG, Haslett C, Sethi T (2008) Galectin-3 reduces the severity of pneumococcal pneumonia by augmenting neutrophil function. Am J Pathol 172:395-405

56. Elmwall J, Kwiecinski J, Na M, Ali AA, Osla V, Shaw LN, Wang W, Sävman K, Josefsson E, Bylund J, Jin T, Welin A, Karlsson A (2017) Galectin-3 Is a target for proteases involved in the virulence of Staphylococcus aureus. Infect Immun 85:e00177-e00117

57. Kolar SL, Ibarra JA, Rivera FE, Mootz JM, Davenport JE, Stevens SM, Horswill AR, Shaw LN (2013) Extracellular proteases are key mediators of Staphylococcus aureus virulence via the global modulation of virulence-determinant stability. Microbiologyopen 2:18-34

58. Prasad L, Leduc Y, Hayakawa K, Delbaere LT (2004) The structure of a universally employed enzyme: V8 protease from Staphylococcus aureus. Acta Crystallogr D Biol Crystallogr 60:256-259

59. Rice K, Peralta R, Bast D, de Azavedo J, McGavin MJ (2001) Description of staphylococcus serine protease ( $\mathrm{ssp}$ ) operon in Staphylococcus aureus and nonpolar inactivation of sspAencoded serine protease. Infect Immun 69:159-169

60. Prokesová L, Potuzníková B, Potempa J, Zikán J, Radl J, Hachová L, Baran K, Porwit-Bobr Z, John C (1992) Cleavage of human immunoglobulins by serine proteinase from Staphylococcus aureus. Immunol Lett 31:259-265

61. Ryan MH, Petrone D, Nemeth JF, Barnathan E, Björck L, Jordan RE (2008) Proteolysis of purified IgGs by human and bacterial enzymes in vitro and the detection of specific proteolytic fragments of endogenous IgG in rheumatoid synovial fluid. Mol Immunol 45:1837-1846

62. Von Pawel-Rammingen U (2012) Streptococcal IdeS and its impact on immune response and inflammation. J Innate Immun 4:132-140

63. Zhang L, Jacobsson K, Ström K, Lindberg M, Frykberg L (1999) Staphylococcus aureus expresses a cell surface protein that binds both IgG and $\beta 2$-glycoprotein I. Microbiology 145:177-183

64. Burman JD, Leung E, Atkins KL, O’Seaghdha MN, Lango L, Bernadó P et al (2008) Interaction of human complement with
Sbi, a staphylococcal immunoglobulin-binding protein: indications of a novel mechanism of complement evasion by Staphylococcus aureus. J Biol Chem 283:17579-17593

65. Brezski RJ, Vafa O, Petrone D, Tam SH, Powers G, Ryan MH, Luongo JL, Oberholtzer A, Knight DM, Jordan RE (2009) Tumor-associated and microbial proteases compromise host IgG effector functions by a single cleavage proximal to the hinge. Proc Natl Acad Sci USA 106:17864-17869

66. Jordan RE, Fernandez J, Brezski RJ, Greenplate AR, Knight DM, Raju TS, Lynch AS (2016) A peptide immunization approach to counteract a Staphylococcus aureus protease defense against host immunity. Immunol Lett 172:29-39

67. Berti AD, Shukla N, Rottier AD, McCrone JS, Turner HM, Monk IR, Baines SL, Howden BP, Proctor RA, Rose WE (2018) Daptomycin selects for genetic and phenotypic adaptations leading to antibiotic tolerance in MRSA. J Antimicrob Chemother 73:2030-2033

68. Wang B, McHugh BJ, Qureshi A, Campopiano DJ, Clarke DJ, Fitzgerald JR, Dorin JR, Weller R, Davidson DJ (2017) IL-1 $\beta$ induced protection of keratinocytes against Staphylococcus aureus-secreted proteases is mediated by human $\beta$-defensin 2 . J Invest Dermatol 37:95-105

69. Ohnemus U, Kohrmeyer K, Houdek P, Rohde H, Wladykowski E, Vidal S, Horstkotte MA, Aepfelbacher M, Kirschner N, Behne MJ, Moll I, Brandner JM (2008) Regulation of epidermal tightjunctions (TJ) during infection with exfoliative toxin-negative Staphylococcus strains. J Invest Dermatol 128:906-916

70. Hirasawa Y, Takai T, Nakamura T, Mitsuishi K, Gunawan H, Suto H, Ogawa T, Wang XL, Ikeda S, Okumura K, Ogawa H (2010) Staphylococcus aureus extracellular protease causes epidermal barrier dysfunction. J Invest Dermatol 130:614-617

71. Fey PD, Endres JL, Yajjala VK, Widhelm TJ, Boissy RJ, Bose JL (2013) A genetic resource for rapid and comprehensive phenotype screening of nonessential Staphylococcus aureus genes. MBio 4:e00537-e00512

72. Abe T, Sugano E, Saigo Y, Tamai M (2003) Interleukin-1beta and barrier function of retinal pigment epithelial cells (ARPE19): aberrant expression of junctional complex molecules. Invest Ophthalmol Vis Sci 44:4097e104

73. Geissler S, Götz F, Kupke T (1996) Serine protease EpiP from Staphylococcus epidermidis catalyzes the processing of the epidermin precursor peptide. J Bacteriol 178:284-288

74. Kuhn ML, Prachi P, Minasov G, Shuvalova L, Ruan J, Dubrovska I, Winsor J, Giraldi M, Biagini M, Liberatori S, Savino S, Bagnoli F, Anderson WF, Grandi G (2014) Structure and protective efficacy of the Staphylococcus aureus autocleaving protease EpiP. FASEB J 28:1780-1793

75. Edwards RJ, Taylor GW, Ferguson M, Murray S, Rendell N, Wrigley A, Bai Z, Boyle J, Finney SJ, Jones A, Russell HH, Turner C, Cohen J, Faulkner L, Sriskandan S (2005) Specific $\mathrm{C}$-terminal cleavage and inactivation of interleukin- 8 by invasive disease isolates of Streptococcus pyogenes. J Infect Dis 192:783-790

76. Zinkernagel AS, Peyssonnaux C, Johnson RS, Nizet V (2008) Pharmacologic augmentation of hypoxia-inducible factor-1alpha with mimosine boosts the bactericidal capacity of phagocytes. J Infect Dis 197:214-217

77. Bukowski M, Wladyka B, Dubin G (2010) Exfoliative toxins of Staphylococcus aureus. Toxins (Basel) 2:1148-1165

78. Amagai M, Yamaguchi T, Hanakawa Y, Nishifuji K, Sugai M, Stanley JR (2002) Staphylococcal exfoliative toxin B specifically cleaves desmoglein 1. J Invest Dermatol 118:845-850

79. Getsios S, Amargo EV, Dusek RL, Ishii K, Sheu L, Godsel LM, Green KJ (2004) Coordinated expression of desmoglein 1 and desmocollin 1 regulates intercellular adhesion. Differentiation 72:419-433 
80. Lisa RWP, Delia MG, Markus W, Carleen MC (2000) Recombinant Staphylococcus aureus exfoliative toxins are not bacterial superantigens. Infect Immun 68:3048-3052

81. Nishifuji K, Sugai M, Amagai M (2008) Staphylococcal exfoliative toxins: "molecular scissors" of bacteria that attack the cutaneous defense barrier in mammals. J Dermatol Sci 49:21-31

82. Pimentel de Araujo F, Tinelli M, Battisti A, Ercoli A, Anesi A, Pantosti A, Monaco M (2018) An outbreak of skin infections in neonates due to a Staphylococcus aureus strain producing the exfoliative toxin A. Infection 46:49-54

83. Vath GM, Earhart CA, Monie DD, Iandolo JJ, Schlievert PM, Ohlendorf DH (1999) The crystal structure of exfoliative toxin B: a superantigen with enzymatic activity. Biochemistry 38:10239-10246

84. Dubin G (2002) Extracellular proteases of Staphylococcus spp. Biol Chem 383:1075-1086

85. Hanakawa Y, Selwood T, Woo D, Lin C, Schechter NM, Stanley JR (2003) Calcium-dependent conformation of desmoglein 1 is required for its cleavage by exfoliative toxin. J Invest Dermatol 121:383-389

86. Ladhani S, Poston SM, Joannou CL, Evans RW (1999) Staphylococcal scalded skin syndrome: exfoliative toxin A (ETA) induces serine protease activity when combined with A431 cells. Acta Paediatr 88:776-779

87. Katayama Y, Baba T, Sekine M, Fukuda M, Hiramatsu K (2013) Betahemolysin promotes skin colonization by Staphylococcus aureus. J Bacteriol 195:1194-1203

88. Baba T, Bae T, Schneewind O, Takeuchi F, Hiramatsu K (2008) Genome sequence of Staphylococcus aureus strain Newman and comparative analysis of staphylococcal genomes: polymorphism and evolution of two major pathogenicity islands. J Bacteriol 190:300-310

89. Zdzalik M, Karim AY, Wolski K, Buda P, Wojcik K, Brueggemann S, Wojciechowski P, Eick S, Calander AM et al (2012) Prevalence of genes encoding extracellular proteases in Staphylococcus aureus - important targets triggering immune response in vivo. FEMS Immunol Med Microbiol 66:220-229

90. Reed SB, Wesson CA, Liou LE, Trumble WR, Schlievert PM, Bohach GA, Bayles KW (2001) Molecular characterization of a novel Staphylococcus aureus serine protease operon. Infect Immun 69:1521-1527

91. Holtfreter S, Nguyen TT, Wertheim H, Steil L, Kusch H, Truong QP, Engelmann S, Hecker M, Völker U, van Belkum A, Bröker BM (2009) Human immune proteome in experimental colonization with Staphylococcus aureus. Clin Vaccine Immunol 16:1607-1614

92. Popowicz GM, Dubin G, Stec-Niemczyk J, Czarny A, Dubin A, Potempa J, Holak TA (2006) Functional and structural characterization of Spl proteases from Staphylococcus aureus. J Mol Biol 358:270-279

93. Zdzalik M, Kalinska M, Wysocka M, Stec-Niemczyk J, Cichon P, Stach N, Gruba N, Stennicke HR, Jabaiah A et al (2013) Biochemical and structural characterization of SplD protease from Staphylococcus aureus. PLoS One 8:e76812

94. Hayashida A, Bartlett AH, Foster TJ, Park PW (2009) Staphylococcus aureus beta-toxin induces lung injury through syndecan-1. Am J Pathol 174:509-518

95. Nygaard TK, Pallister KB, Ruzevich P, Griffith S, Vuong C, Voyich JM (2010) SaeR binds a consensus sequence within virulence gene promoters to advance USA300 pathogenesis. J Infect Dis 201:241-254

96. Diep BA, Afasizheva A, Le HN, Kajikawa O, Matute-Bello G, Tkaczyk C, Sellman B, Badiou C, Lina G, Chambers HF (2013) Effects of linezolid on suppressing in vivo production of staphylococcal toxins and improving survival outcomes in a rabbit model of methicillin-resistant Staphylococcus aureus necrotizing pneumonia. J Infect Dis 208:75-82

97. Pustelny K, Stach N, Wladyka B, Dubin A, Dubin G (2014) Evaluation of P1' substrate specificity of staphylococcal SplB protease. Acta Biochim Pol 61:149-152

98. Stec-Niemczyk J, Pustelny K, Kisielewska M, Bista M, Boulware KT, Stennicke HR, Thogersen IB, Daugherty PS et al (2009) Structural and functional characterization of SplA, an exclusively specific protease of Staphylococcus aureus. Biochem J 419:555-564

99. Dubin G, Stec-Niemczyk J, Kisielewska M, Pustelny K, Popowicz GM, Bista M, Kantyka T, Boulware KT, Stennicke HR, Czarna A et al (2008) Enzymatic activity of the Staphylococcus aureus SplB serine protease is induced by substrates containing the sequence Trp-Glu-Leu-Gln. J Mol Biol 379:343-356

100. Stentzel S, Teufelberger A, Nordengrün M, Kolata J, Schmidt F, van Crombruggen K et al (2016) Staphylococcal serine protease-like proteins are pacemakers of allergic airway reactions to Staphylococcus aureus. J Allergy Clin Immunol 9:492-500

101. Stentzel S, Teufelberger A, Nordengrün M, Kolata J, Schmidt F, van Crombruggen K, Michalik S, Kumpfmüller J, Tischer S et al (2017) Staphylococcal serine protease-like proteins are pacemakers of allergic airway reactions to Staphylococcus aureus. J Allergy Clin Immunol 139:492-500

102. Pang YY, Schwartz J, Thoendel M, Ackermann LW, Horswill AR, Nauseef WM (2010) agr-Dependent interactions of Staphylococcus aureus USA300 with human polymorphonuclear neutrophils. J Innate Immun 2:546-559

103. Kebaier C, Chamberland RR, Allen IC, Gao X, Broglie PM, Hall JD, Jania C, Doerschuk CM, Tilley SL, Duncan JA (2012) Staphylococcus aureus $\alpha$-hemolysin mediates virulence in a murine model of severe pneumonia through activation of the NLRP3 inflammasome. J Infect Dis 205:807-817

104. Paharik AE, Salgado-Pabon W, Meyerholz DK, White MJ, Schlievert PM, Horswill AR (2016) The Spl serine proteases modulate Staphylococcus aureus protein production and virulence in a rabbit model of pneumonia mSphere 1(5)

105. O’Brien L, Kerrigan SW, Kaw G, Hogan M, Penadés J, Litt D, Fitzgerald DJ, Foster TJ, Cox D (2002) Multiple mechanisms for the activation of human platelet aggregation by Staphylococcus aureus: roles for the clumping factors ClfA and ClfB, the serine-aspartate repeat protein SdrE and protein A. Mol Microbiol 44:1033-1044

106. Davies JR, Kirkham S, Svitacheva N, Thornton DJ, Carlstedt I (2007) MUC16 is produced in tracheal surface epithelium and submucosal glands and is present in secretions from normal human airway and cultured bronchial epithelial cells. Int J Biochem Cell Biol 39:1943-1954

107. Blalock TD, Spurr-Michaud SJ, Tisdale AS, Gipson IK (2008) Release of membrane-associated mucins from ocular surface epithelia. Invest Ophthalmol Vis Sci 49:1864-1871

108. Govindarajan B, Menon BB, Spurr-Michaud S, Rastogi K, Gilmore MS, Argüeso P, Gipson IK (2012) A metalloproteinase secreted by Streptococcus pneumoniae removes membrane mucin MUC16 from the epithelial glycocalyx barrier. PLoS One 7:e32418

109. Gipson IK, Spurr-Michaud S, Tisdale A, Menon BB (2014) Comparison of the transmembrane mucins MUC1 and MUC16 in epithelial barrier function. PLoS One 9:e100393

110. Haridas D, Ponnusamy MP, Chugh S, Lakshmanan I, Seshacharyulu P, Batra SK (2014) MUC16: molecular analysis and its functional implications in benign and malignant conditions. FASEB J 28:4183-4199

111. Belyi Y, Rybolovlev I, Polyakov N, Chernikova A, Tabakova I, Gintsburg A (2018) Staphylococcus aureus surface protein G 
is an immunodominant protein and a possible target in an antibiofilm drug development. Open Microbiol J 12:94-106

112. Ewa B, Maciej W, Marcin S, Grzegorz D, Michał Z, Jan P, Józef O (2012) The development of first Staphylococcus aureus SplB protease inhibitors: phosphonic analogues of glutamine. Bioorg Med Chem Lett 22:5574-5578

113. Bachert C, van Steen K, Zhang N, Holtappels G, Cattaert T, Maus B, Buhl R, Taube C, Korn S, Kowalski M, Bousquet J, Howarth P (2012) Specific IgE against Staphylococcus aureus enterotoxins: an independent risk factor for asthma. J Allergy Clin Immunol 130:376-381

114. Huvenne W, Hellings PW, Bachert C (2013) Role of staphylococcal superantigens in airway disease. Int Arch Allergy Immunol 161:304-314

115. Teufelberger AR, Nordengrün M, Braun $H$, Maes $T$, De Grove K, Holtappels G, O’Brien C, Provoost S, Hammad H, Gonçalves A et al (2018) The IL-33/ST2 axis is crucial in type 2 airway responses induced by Staphylococcus aureus-derived serine protease-like protein D. J Allergy Clin Immunol 141:549-559

116. Lefrancais E, Roga S, Gautier V, Gonzalez-de-Peredo A, Monsarrat B, Girard JP, Cayrol C (2012) IL-33 is processed into mature bioactive forms by neutrophil elastase and cathepsin G. Proc Natl Acad Sci USA 109:1673-1678

117. Lambrecht BN, Hammad H (2015) The immunology of asthma. Nat Immunol 16:45-56

118. van Helden MJ, Lambrecht BN (2013) Dendritic cells in asthma. Curr Opin Immunol 25:745-754

119. Rank MA, Kobayashi T, Kozaki H, Bartemes KR, Squillace DL, Kita H (2009) IL-33-activated dendritic cells induce an atypical TH2-type response. J Allergy Clin Immunol 123:1047-1054

120. Besnard AG, Togbe D, Guillou N, Erard F, Quesniaux V, Ryffel B (2011) IL-33-activated dendritic cells are critical for allergic airway inflammation. Eur J Immunol 41:1675-1686

121. Maes T, Provoost S, Lanckacker EA, Cataldo DD, Vanoirbeek JA, Nemery B, Tournoy KG, Joos GF (2010) Mouse models to unravel the role of inhaled pollutants on allergic sensitization and airway inflammation. Respir Res 11:7

122. Huvenne W, Callebaut I, Plantinga M, Vanoirbeek JA, Krysko O, Bullens DM, Gevaert P, Van Cauwenberge P, Lambrecht BN, Ceuppens JL, Bachert C, Hellings PW (2010) Staphylococcus aureus enterotoxin $\mathrm{B}$ facilitates allergic sensitization in experimental asthma. Clin Exp Allergy 40:1079-1090

123. Krysko O, Maes T, Plantinga M, Holtappels G, Imiru R, Vandenabeele P, Joos G, Krysko DV, Bachert C (2013) The adjuvantlike activity of staphylococcal enterotoxin $B$ in a murine asthma model is independent of IL-1R signaling. Allergy 68:446-453

124. Hammad H, Chieppa M, Perros F, Willart MA, Germain RN, Lambrecht BN (2009) House dust mite allergen induces asthma via Toll-like receptor 4 triggering of airway structural cells. Nat Med 15:410-416

125. Matsui K, Nishikawa A (2012) Peptidoglycan from Staphylococcus aureus induces TH2 immune response in mice. J Investig Allergol Clin Immunol 22:80-86

126. Matsuwaki Y, Wada K, White TA, Benson LM, Charlesworth MC, Checkel JL et al (2009) Recognition of fungal protease activities induces cellular activation and eosinophil-derived neurotoxin release in human eosinophils. J Immunol 183:6708-6716

127. Boitano S, Flynn AN, Schulz SM, Hoffman J, Price TJ, Vagner J (2011) Potent agonists of the protease activated receptor 2 (PAR2). J Med Chem 54:1308-1313

128. de Boer JD, Van't Veer C, Stroo I, van der Meer AJ, de Vos AF, van der Zee JS, Roelofs JJ5, van der Poll T (2014) Proteaseactivated receptor- 2 deficient mice have reduced house dust miteevoked allergic lung inflammation. Innate Immun 20:618-625

129. Takai T, Kato T, Ota M, Yasueda H, Kuhara T, Okumura K, Ogawa H (2005) Recombinant Der p 1 and Der $f 1$ with in vitro enzymatic activity to cleave human CD23, CD25 and alpha1antitrypsin, and in vivo IgE-eliciting activity in mice. Int Arch Allergy Immunol 137:194-200

130. Hartl D, Latzin P, Hordijk P, Marcos V, Rudolph C, Woischnik M, Krauss-Etschmann S, Koller B, Reinhardt D, Roscher AA, Roos D, Griese M (2007) Cleavage of CXCR1 on neutrophils disables bacterial killing in cystic fibrosis lung disease. Nat Med 13:1423-1430

131. Rieneck K, Renneberg J, Diamant M, Gutschik E, Bendtzen K (1997) Molecular cloning and expression of a novel Staphylococcus aureus antigen. Biochim Biophys Acta 1350:128-132

132. Stach N, Kalinska M, Zdzalik M, Kitel R, Karim A, Serwin K, Rut W, Larsen K, Jabaiah A, Firlej M, Wladyka B, Daugherty P, Stennicke H, Drag M, Potempa J, Dubin G (2018) Unique substrate specificity of SplE serine protease from Staphylococcus aureus. Structure 26:572-579.e4

133. Banbula A, Potempa J, Travis J, Fernandez-Catalán C, Mann K, Huber R, Bode W, Medrano F (1998) Amino-acid sequence and three-dimensional structure of the Staphylococcus aureus metalloproteinase at 1.72 A resolution. Structure 6:1185-1193

134. Nickerson NN, Joag V, McGavin MJ (2008) Rapid autocatalytic activation of the M4 metalloprotease aureolysin is controlled by a conserved $\mathrm{N}$-terminal fungalysin-thermolysinpropeptide domain. Mol Microbiol 69:1530-1543

135. Laarman AJ, Ruyken M, Malone CL, van Strijp JA, Horswill AR, Rooijakkers SH (2011) Staphylococcus aureus metalloprotease aureolysin cleaves complement $\mathrm{C} 3$ to mediate immune evasion. J Immunol 186:6445-6453

136. de Haas CJ, Veldkamp KE, Peschel A, Weerkamp F, Van Wamel WJ, Heezius EC, Poppelier MJ, Van Kessel KP, van Strijp JA (2004) Chemotaxis inhibitory protein of Staphylococcus aureus, a bacterial antiinflammatory agent. J Exp Med 199:687-695

137. Postma B, Poppelier MJ, van Galen JC, Prossnitz ER, van Strijp JA, de Haas CJ, van Kessel KP (2004) Chemotaxis inhibitory protein of Staphylococcus aureus binds specifically to the C5a and formylated peptide receptor. J Immunol 172:6994-7001

138. McAleese FM, Walsh EJ, Sieprawska M, Potempa J, Foster TJ (2001) Loss of clumping factor B fibrinogen binding activity by Staphylococcus aureus involves cessation of transcription, shedding and cleavage by metalloprotease. J Biol Chem 276:29969-29978

139. Lauderdale KJ, Boles BR, Cheung AL, Horswill AR (2009) Interconnections between Sigma B, agr, and proteolytic activity in Staphylococcus aureus biofilm maturation. Infect Immun 77:1623-1635

140. Loughran AJ, Atwood DN, Anthony AC, Harik NS, Spencer HJ, Beenken KE, Smeltzer MS (2014) Impact of individual extracellular proteases on Staphylococcus aureus biofilm formation in diverse clinical isolates and their isogenic sarA mutants. Microbiologyopen 3:897-909

141. Burlak C, Hammer CH, Robinson MA, Whitney AR, McGavin MJ, Kreiswirth BN, Deleo FR (2007) Global analysis of community-associated methicillin-resistant Staphylococcus aureus exoproteins reveals molecules produced in vitro and during infection. Cell Microbiol 9:1172-1190

142. Kubica M, Guzik K, Koziel J, Zarebski M, Richter W, Gajkowska B, Golda A, Maciag-Gudowska A, Brix K, Shaw L, Foster T, Potempa J (2008) A potential new pathway for Staphylococcus aureus dissemination: the silent survival of $S$. aureus phagocytosed by human monocyte-derived macrophages. PLoS One 3:e1409

143. Beaufort N, Wojciechowski P, Sommerhoff CP, Szmyd G, Dubin G, Eick S, Kellermann J, Schmitt M, Potempa J, Magdolen V (2008) The human fibrinolytic system is a target for the staphylococcal metalloprotease aureolysin. Biochem J 410:157-165 
144. Saravanan R, Adav SS, Choong YK, van der Plas MJA, Petrlova J, Kjellström S, Sze SK, Schmidtchen A (2017) Proteolytic signatures define unique thrombin-derived peptides present in human wound fluid in vivo. Sci Rep 7:13136

145. Singh VK, Carlos MR, Singh K (2010) Physiological significance of the peptidoglycan hydrolase, LytM, in Staphylococcus aureus. FEMS Microbiol Lett 311:167-175

146. Firczuk M, Mucha A, Bochtler M (2005) Crystal structures of active LytM. J Mol Biol 354:578-590

147. Odintsov SG, Sabala I, Marcyjaniak M, Bochtler M (2004) Latent LytM at 1.3A resolution. J Mol Biol 335:775-785

148. Osipovitch DC, Griswold KE (2015) Fusion with a cell wall binding domain renders autolysin LytM a potent anti-Staphylococcus aureus agent. FEMS Microbiol Lett 362:1-7

149. Bochtler M, Odintsov SG, Marcyjaniak M, Sabala I (2004) Similar active sites in lysostaphins and D-Ala-D-Ala metallopeptidases. Protein Sci 13:854-861

150. Pieper R, Gatlin-Bunai CL, Mongodin EF, Parmar PP, Huang ST, Clark DJ, Fleischmann RD, Gill SR, Peterson SN (2006) Comparative proteomic analysis of Staphylococcus aureus strains with differences in resistance to the cell wall-targeting antibiotic vancomycin. Proteomics 6:4246-4258

151. Renzoni A, Barras C, François P, Charbonnier Y, Huggler E, Garzoni C, Kelley WL, Majcherczyk P, Schrenzel J, Lew DP, Vaudaux P (2006) Transcriptomic and functional analysis of an autolysis-deficient, teicoplanin-resistant derivative of methicillinresistant Staphylococcus aureus. Antimicrob Agents Chemother 50:3048-3061

152. Ingavale SS, Van Wamel W, Cheung AL (2003) Characterization of RAT, an autolysis regulator in Staphylococcus aureus. Mol Microbiol 48:1451-1466

153. Borišek J, Pintar S, Ogrizek M, Grdadolnik SG, Hodnik V, Turk D, Perdih A, Novič M (2018) Discovery of (phenylureido) piperidinyl benzamides as prospective inhibitors of bacterial autolysin E from Staphylococcus aureus. J Enzyme Inhib Med Chem 33:1239-1247

154. Porayath C, Suresh MK, Biswas R, Nair BG, Mishra N, Pal S (2018) Autolysin mediated adherence of Staphylococcus aureus with Fibronectin, Gelatin and Heparin. Int J Biol Macromol 110:179-184

155. Binsker U, Palankar R, Wesche J, Kohler TP, Prucha J, Burchhardt G, Rohde M, Schmidt F, Bröker BM, Mamat U, Pané-Farré J, Graf A, Ebner P, Greinacher A, Hammerschmidt S (2018) Secreted immunomodulatory proteins of Staphylococcus aureus activate platelets and induce platelet aggregation. Thromb Haemost 118:745-757

156. Tiwari KB, Gatto C, Walker S, Wilkinson BJ (2018) Exposure of Staphylococcus aureus to targocil blocks translocation of the major autolysin Atl across the membrane, resulting in a significant decrease in autolysis. Antimicrob Agents Chemother 62:e00323-e00318

157. Pietiäinen M, François $P$, Hyyryläinen HL, Tangomo M, Sass V, Sahl HG, Schrenzel J, Kontinen VP (2009) Transcriptome analysis of the responses of Staphylococcus aureus to antimicrobial peptides and characterization of the roles of vraDE and vraSR in antimicrobial resistance. BMC Genom 10:429

158. Thumm G, Götz F (1997) Studies on prolysostaphin processing and characterization of the lysostaphin immunity factor (Lif) of Staphylococcus simulans biovar staphylolyticus. Mol Microbiol 23:1251-1265

159. Raulinaitis V, Tossavainen H, Aitio O, Juuti JT, Hiramatsu K, Kontinen V, Permi P (2017) Identification and structural characterization of LytU, a unique peptidoglycan endopeptidase from the lysostaphin family. Sci Rep 7:6020

160. McAdow M, Missiakas DM, Schneewind O (2012) Staphylococcus aureus secretes coagulase and von Willebrand factor binding protein to modify the coagulation cascade and establish host infections. J Innate Immun 4:141-148

161. Friedrich R, Panizzi P, Fuentes-Prior P, Richter K, Verhamme I, Anderson PJ, Kawabata S, Huber R, Bode W, Bock PE (2003) Staphylocoagulase is a prototype for the mechanism of cofactor-induced zymogen activation. Nature 425:535-539

162. Cheung AI, Projan SJ, Edelstein RE, Fischetti VA (1995) Cloning, expression, and nucleotide sequence of a Staphylococcus aureus gene (fbpA) encoding a fibrinogen-binding protein. Infect Immun 63:1914-1920

163. Kawabata S, Morita T, Iwanaga S, Igarashi H (1985) Enzymatic properties of staphylothrombin, an active molecular complex formed between staphylocoagulase and human prothrombin. J Biochem 98:1603-1614

164. Panizzi P, Friedrich R, Fuentes-Prior P, Richter K, Bock PE, Bode W (2006) Fibrinogen substrate recognition by staphylocoagulase (pro)thrombin complexes. J Biol Chem 281:1179-1187

165. Cheng AG, McAdow M, Kim HK, Bae T, Missiakas DM, Schneewind O (2010) Contribution of coagulases towards Staphylococcus aureus disease and protective immunity. PLoS Pathog 6:e1001036

166. Walker JN, Crosby HA, Spaulding AR, Salgado-Pabón W, Malone CL, Rosenthal CB, Schlievert PM, Boyd JM, Horswill AR (2013) The Staphylococcus aureus ArlRS two-component system is a novel regulator of agglutination and pathogenesis. PLoS Pathog 9:e1003819

167. Hijikata-Okunomiya A, Kataoka N (2003) Argatroban inhibits staphylothrombin. J Thromb Haemost 1:2060-2061

168. Vanassche T, Verhaegen J, Peetermans WE, Hoylaerts MF, Verhamme P (2010) Dabigatran inhibits Staphylococcus aureus coagulase activity. J Clin Microbiol 48:4248-4250

169. Bjerketorp J, Nilsson M, Ljungh A, Flock JI, Jacobsson K, Frykberg L (2002) A novel von Willebrand factor binding protein expressed by Staphylococcus aureus. Microbiology 148:2037-2044

170. Bjerketorp J, Jacobsson K, Frykberg L (2004) The von Willebrand factor-binding protein (vWbp) of Staphylococcus aureus is a coagulase. FEMS Microbiol Lett 234:309-314

171. Kroh HK, Panizzi P, Bock PE (2009) Von Willebrand factorbinding protein is a hysteretic conformational activator of prothrombin. Proc Natl Acad Sci USA 1106:7786-7791

172. Thomer L, Schneewind O, Missiakas D (2013) Multiple ligands of von Willebrand factor-binding protein ( $\mathrm{vWbp}$ ) promote Staphylococcus aureus clot formation in human plasma. J Biol Chem 288:28283-28292

173. Claes J, Liesenborghs L, Peetermans M, Veloso TR, Missiakas D, Schneewind O, Mancini S, Entenza JM, Hoylaerts MF, Heying R, Verhamme P, Vanassche T (2017) Clumping factor A, von Willebrand factor-binding protein and von Willebrand factor anchor Staphylococcus aureus to the vessel wall. J Thromb Haemost 15:1009-1019

174. Claes J, Ditkowski B, Liesenborghs L, Veloso TR, Entenza JM, Moreillon P, Vanassche T, Verhamme P, Hoylaerts MF, Heying R (2018) Assessment of the dual role of clumping factor A in $\mathrm{S}$. aureus adhesion to endothelium in absence and presence of plasma. Thromb Haemost 118:1230-1241

175. McAdow M, Kim HK, Dedent AC, Hendrickx AP, Schneewind O, Missiakas DM (2011) Preventing Staphylococcus aureus sepsis through the inhibition of its agglutination in blood. PLoS Pathog 7:e1002307

176. Craven RR, Gao X, Allen IC, Gris D, Bubeck Wardenburg J, McElvania-Tekippe E, Ting JP, Duncan JA (2009) Staphylococcus aureus alpha-hemolysin activates the NLRP3-inflammasome in human and mouse monocytic cells. PLoS One 4:e7446 
177. Cheung AL, Projan SJ (1994) Cloning and sequencing of sarA of Staphylococcus aureus, a gene required for the expression of agr. J Bacteriol 176:4168-4172

178. Xiong YQ, Willard J, Yeaman MR, Cheung AL, Bayer AS (2006) Regulation of Staphylococcus aureus alpha-toxin gene (hla) expression by agr, sarA, and sae in vitro and in experimental infective endocarditis. J Infect Dis 194:1267-1275

179. Zhou Y, Chen C, Pan J, Deng X, Wang J (2018) Epigallocatechin gallate can attenuate human alveolar epithelial cell injury induced by alpha-haemolysin. Microb Pathog 115:222-226

180. Horn J, Klepsch M, Manger M, Wolz C, Rudel T, Fraunholz M (2018) The long non-coding RNA SSR42 controls Staphylococcus aureus $\alpha$-toxin transcription in response to environmental stimuli. J Bacteriol. https://doi.org/10.1128/JB.00252-18 (Epub ahead of print)

181. Essmann F, Bantel H, Totzke G, Engels IH, Sinha B, SchulzeOsthoff K, Jänicke RU (2003) Staphylococcus aureus alphatoxin-induced cell death: predominant necrosis despite apoptotic caspase activation. Cell Death Differ 10:1260-1272

182. Inoshima I, Inoshima N, Wilke GA, Powers ME, Frank KM, Wang Y, Bubeck Wardenburg J (2011) A Staphylococcus aureus pore-forming toxin subverts the activity of ADAM10 to cause lethal infection in mice. Nat Med 17:1310-1314

183. Smith KM, Gaultier A, Cousin H, Alfandari D, White JM, DeSimone DW (2002) The cysteine-rich domain regulates ADAM protease function in vivo. J Cell Biol 159:893-902

184. Moss ML, Bartsch JW (2004) Therapeutic benefits from targeting of ADAM family members. Biochemistry 43:7227-7235

185. Blobel CP (2005) ADAMs: key components in EGFR signalling and development. Nat Rev Mol Cell Biol 6:32-43

186. Wilke GA, Bubeck Wardenburg J (2010) Role of a disintegrin and metalloprotease 10 in Staphylococcus aureus alphahemolysin-mediated cellular injury. Proc Natl Acad Sci USA 107:13473-13478

187. Olaniyi RO, Pancotto L, Grimaldi L, Bagnoli F (2018) Deciphering the pathological role of staphylococcal $\alpha$-toxin and pantonvalentine leukocidin using a novel Ex Vivo human skin model. Front Immunol 9:951

188. Smith IDM, Milto KM, Doherty CJ, Amyes SGB, Simpson AHRW, Hall AC (2018) A potential key role for alpha-haemolysin of Staphylococcus aureus in mediating chondrocyte death in septic arthritis. Bone Jt Res 7:457-467

189. Keitsch S, Riethmüller J, Soddemann M, Sehl C, Wilker B, Edwards MJ, Caldwell CC, Fraunholz M, Gulbins E, Becker KA (2018) Pulmonary infection of cystic fibrosis mice with Staphylococcus aureus requires expression of $\alpha$-toxin. Biol Chem. https ://doi.org/10.1515/hsz-2018-0161 (Epub ahead of print)

190. Surewaard BGJ, Thanabalasuriar A, Zeng Z, Tkaczyk C, Cohen TS, Bardoel BW, Jorch SK, Deppermann C, Bubeck Wardenburg J, Davis RP, Jenne CN, Stover KC, Sellman BR, Kubes P (2018) $\alpha$-Toxin induces platelet aggregation and liver injury during Staphylococcus aureus sepsis. Cell Host Microbe 24:271-284

191. Ortines RV, Liu H, Cheng LI, Cohen TS, Lawlor H, Gami A, Wang Y, Dillen CA, Archer NK, Miller RJ, Ashbaugh AG, Pinsker BL, Marchitto MC, Tkaczyk C, Stover CK, Sellman BR, Miller LS (2018) Neutralizing alpha-toxin accelerates healing of Staphylococcus aureus-infected wounds in nondiabetic and diabetic mice. Antimicrob Agents Chemother 62:e02288-e02217

192. Tkaczyk C, Semenova E, Shi YY, Rosenthal K, Oganesyan V, Warrener P, Stover CK, Sellman BR (2018) Alanine scanning mutagenesis of the MEDI4839 (Suvratoxumab) epitope reduces alpha toxin lytic activity in vitro and $S$. aureus fitness in infection models. Antimicrob Agents Chemother. https://doi.org/10.1128/ AAC.01033-18 (Epub ahead of print)

193. Saleh FA, Freer JH (1984) Inhibition of secretion of staphylococcal alpha toxin by cerulenin. Med Microbiol 18:205-216
194. Teng Z, Shi D, Liu H, Shen Z, Zha Y, Li W, Deng X, Wang J (2017) Lysionotin attenuates Staphylococcus aureus pathogenicity by inhibiting $\alpha$-toxin expression. Appl Microbiol Biotechnol 101:6697-6703

195. Moyano AJ, Racca AC, Soria G, Saka HA, Andreoli V, Smania AM, Sola C, Bocco JL (2018) c-Jun proto-oncoprotein plays a protective role in lung epithelial cells exposed to staphylococcal $\alpha$-toxin. Front Cell Infect Microbiol 8:170

196. Jin Y, Li M, Shang Y, Liu L, Shen X, Lv Z, Hao Z, Duan J, Wu Y, Chen C, Pan J, Yu F (2018) Sub-Inhibitory concentrations of mupirocin strongly inhibit alpha-toxin production in high-level mupirocin-resistant MRSA by down-regulating agr, saeRS, and sarA. Front Microbiol 9:993

197. Xuewen H, Ping O, Zhongwei Y, Zhongqiong Y, Hualin F, Juchun L, Changliang H, Gang S, Zhixiang Y, Xu S, Yuanfeng Z, Lixia L, Lizi Y (2018) Eriodictyol protects against Staphylococcus aureus-induced lung cell injury by inhibiting alphahemolysin expression. World J Microbiol Biotechnol 34:64

198. Chen Y, Chen M, Zhang Y, Lee JH, Escajadillo T, Gong H, Fang RH, Gao W, Nizet V, Zhang L (2018) Broad-spectrum neutralization of pore-forming toxins with human erythrocyte membranecoated nanosponges. Adv Healthc Mater 7:e1701366

199. Ziebandt AK, Weber H, Rudolph J, Schmid R, Höper D, Engelmann S, Hecker M (2001) Extracellular proteins of Staphylococcus aureus and the role of SarA and sigma B. Proteomics 1:480-493

200. Bokarewa MI, Jin T, Tarkowski A (2006) Staphylococcus aureus: Staphylokinase. Int J Biochem Cell Biol 38:504-509

201. Parry MA, Fernandez-Catalan C, Bergner A, Huber R, Hopfner KP, Schlott B, Gührs KH, Bode W (1998) The ternary microplasmin-staphylokinase-microplasmin complex is a proteinasecofactor-substrate complex in action. Nat Struct Biol 5:917-923

202. Silence K, Collen D, Lijnen HR (1993) Interaction between staphylokinase, plasmin(ogen), and alpha 2-antiplasmin. Recycling of staphylokinase after neutralization of the plasminstaphylokinase complex by alpha 2-antiplasmin. J Biol Chem 268:9811-9816

203. Sakharov DV, Lijnen HR, Rijken DC (1996) Interactions between staphylokinase, plasmin(ogen), and fibrin. Staphylokinase discriminates between free plasminogen and plasminogen bound to partially degraded fibrin. J Biol Chem 271:27912-27928

204. Peetermans M, Vanassche T, Liesenborghs L, Lijnen RH, Verhamme P (2016) Bacterial pathogens activate plasminogen to breach tissue barriers and escape from innate immunity. Crit Rev Microbiol 42:866-882

205. Rooijakkers SH, van Wamel WJ, Ruyken M, van Kessel KP, van Strijp JA (2005) Anti-opsonic properties of staphylokinase. Microbes Infect 7:476-484

206. Santala A, Saarinen J, Kovanen P, Kuusela P (1999) Activation of interstitial collagenase, MMP-1, by Staphylococcus aureus cells having surface-bound plasmin: a novel role of plasminogen receptors of bacteria. FEBS Lett 461:153-156

207. Kwiecinski J, Peetermans M, Liesenborghs L, Na M, Björnsdottir H, Zhu X, Jacobsson G, Johansson BR, Geoghegan JA, Foster TJ et al (2016) Staphylokinase control of Staphylococcus aureus biofilm formation and detachment through host plasminogen activation. J Infect Dis 213:139-148

208. Jin T, Bokarewa M, Foster T, Mitchell J, Higgins J, Tarkowski A (2004) Staphylococcus aureus resists human defensins by production of staphylokinase, a novel bacterial evasion mechanism. J Immunol 172:1169-1176

209. Nguyen LT, Vogel HJ (2016) Staphylokinase has distinct modes of interaction with antimicrobial peptides, modulating its plasminogen-activation properties. Sci Rep 6:31817

210. Braff MH, Jones AL, Skerrett SJ, Rubens CE (2007) Staphylococcus aureus exploits cathelicidin antimicrobial peptides 
produced during early pneumonia to promote staphylokinasedependent fibrinolysis. J Infect Dis 195:1365-1372

211. Geisbrecht BV, Hamaoka BY, Perman B, Zemla A, Leahy DJ (2005) The crystal structures of EAP domains from Staphylococcus aureus reveal an unexpected homology to bacterial superantigens. J Biol Chem 280:17243-17250

212. Pham CT (2006) Neutrophil serine proteases: specific regulators of inflammation. Nat Rev Immunol 6:541-550

213. Stapels DA, Ramyar KX, Bischoff M, von Köckritz-Blickwede M, Milder FJ, Ruyken M, Eisenbeis J, McWhorter WJ et al (2014) Staphylococcus aureus secretes a unique class of neutrophil serine protease inhibitors. Proc Natl Acad Sci USA 111:13187-13192

214. Woehl JL, Stapels DAC, Garcia BL, Ramyar KX, Keightley A, Ruyken M, Syriga M, Sfyroera G, Weber AB et al (2014) The extracellular adherence protein from Staphylococcus aureus inhibits the classical and lectin pathways of complement by blocking formation of the $\mathrm{C} 3$ proconvertase. J Immunol 193:6161-6171

215. Palma M, Haggar A, Flock JI (1999) Adherence of Staphylococcus aureus is enhanced by an endogenous secreted protein with broad binding activity. J Bacteriol 181:2840-2845

216. Chavakis T, Hussain M, Kanse SM, Peters G, Bretzel RG, Flock JI, Herrmann M, Preissner KT (2002) Staphylococcus aureus extracellular adherence protein serves as anti-inflammatory factor by inhibiting the recruitment of host leukocytes. Nat Med 8:687-693

217. Edwards AM, Bowden MG, Brown EL, Laabei M, Massey RC (2012) Staphylococcus aureus extracellular adherence protein triggers TNF $\alpha$ release, promoting attachment to endothelial cells via protein A. PLoS One 7:e43046

218. Eisenbeis J, Saffarzadeh M, Peisker H, Jung P, Thewes N, Preissner KT, Herrmann M, Molle V, Geisbrecht BV, Jacobs K, Bischoff M (2018) The Staphylococcus aureus extracellular adherence protein Eap Is a DNA binding protein capable of blocking neutrophil extracellular trap formation. Front Cell Infect Microbiol 8:235

219. Sabat A, Melles DC, Martirosian G, Grundmann H, van Belkum A, Hryniewicz W (2006) Distribution of the serine-aspartate repeat protein-encoding sdr genes among nasal-carriage and invasive Staphylococcus aureus strains. J Clin Microbiol 44:1135-1138

220. Hazenbos WL, Kajihara KK, Vandlen R, Morisaki JH, Lehar SM, Kwakkenbos MJ, Beaumont T, Bakker AQ, Phung Q et al (2013) Novel staphylococcal glycosyltransferases SdgA and SdgB mediate immunogenicity and protection of virulence-associated cell wall proteins. PLoS Pathog 9:e1003653

221. Thomer L, Becker S, Emolo C, Quach A, Kim HK, Rauch S, Anderson M, Leblanc JF, Schneewind O, Faull KF, Missiakas D (2014) N-acetylglucosaminylation of serine-aspartate repeat proteins promotes Staphylococcus aureus bloodstream infection. J Biol Chem 289:3478-3486

222. Chen H, Ricklin D, Hammel M, Garcia BL, McWhorter WJ, Sfyroera G, Wu YQ, Tzekou A, Li S, Geisbrecht BV, Woods VL Jr, Lambris JD (2010) Allosteric inhibition of complement function by a staphylococcal immune evasion protein. Proc Natl Acad Sci USA 107:17621-17626

223. Lee LYL, Liang X, Hook M, Brown EL (2004) Identification and characterization of the $\mathrm{C} 3$ binding domain of the Staphylococcus aureus extracellular fibrinogen-binding protein (Efb). J Biol Chem 279:50710-50716

224. Ko YP, Kang M, Ganesh VK, Ravirajan D, Li B, Höök M (2016) Coagulase and Efb of Staphylococcus aureus have a common fibrinogen binding motif. MBio 7:e01885-e01815

225. Posner MG, Upadhyay A, Abubaker AA, Fortunato TM, Vara D, Canobbio I, Bagby S, Pula G (2016) Extracellular fibrinogen-binding protein (Efb) from Staphylococcus aureus inhibits the formation of platelet-leukocyte complexes. J Biol Chem 291:2764-2776

226. Lee LY, Miyamoto YJ, McIntyre BW, Hook M, McCrea KW, McDevitt D, Brown EL (2002) The Staphylococcus aureus Map protein is an immunomodulator that interferes with T cell-mediated responses. J Clin Invest 110:1461-1471

227. Herman-Bausier P, Valotteau C, Pietrocola G, Rindi S, Alsteens D, Foster TJ, Speziale P, Dufrêne YF (2016) Mechanical strength and inhibition of the Staphylococcus aureus collagen-binding protein Cna. MBio 7:e01529-e01516

228. Madani A, Garakani K, Mofrad MRK (2017) Molecular mechanics of Staphylococcus aureus adhesin, CNA, and the inhibition of bacterial adhesion by stretching collagen. PLoS One 12:e0179601

229. Gaboriaud C, Thielens NM, Gregory LA, Rossi V, FontecillaCamps JC, Arlaud GJ (2004) Structure and activation of the C1 complex of complement: unraveling the puzzle. Trends Immunol 25:368-373

230. Wallis R, Mitchell DA, Schmid R, Schwaeble WJ, Keeble AH (2010) Paths reunited: Initiation of the classical and lectin pathways of complement activation. Immunobiology 215:1-11

231. Valotteau C, Prystopiuk V, Pietrocola G, Rindi S, Peterle D, De Filippis V, Foster TJ, Speziale P, Dufrêne YF (2017) Single-cell and single-molecule analysis unravels the multifunctionality of the Staphylococcus aureus collagen-binding protein cna. ACS Nano 11:2160-2170

232. Rooijakkers SH, Milder FJ, Bardoel BW, Ruyken M, van Strijp JA, Gros P (2007) Staphylococcal complement inhibitor: structure and active sites. J Immunol 179:2989-2998

233. Jongerius I, Puister M, Wu J, Ruyken M, van Strijp JA, Rooijakkers SH (2010) Staphylococcal complement inhibitor modulates phagocyte responses by dimerization of convertases. J Immunol 184:420-425

234. Rooijakkers SH, Ruyken M, Roos A, Daha MR, Presanis JS, Sim RB, van Wamel WJ, van Kessel KP, van Strijp JA (2005) Immune evasion by a staphylococcal complement inhibitor that acts on C3 convertases. Nat Immunol 6:920-927

235. Hoekstra H, Romero Pastrana F, Bonarius HPJ, van Kessel KPM, Elsinga GS, Kooi N, Groen H, van Dijl JM, Buist G (2018) A human monoclonal antibody that specifically binds and inhibits the staphylococcal complement inhibitor protein SCIN. Virulence 9:70-82

236. Langley R, Patel D, Jackson N, Clow F, Fraser JD (2010) Staphylococcal superantigen super-domains in immune evasion. Crit Rev Immunol 30:149-165

237. Hermans SJ, Baker HM, Sequeira RP, Langley RJ, Baker EN, Fraser JD (2012) Structural and functional properties of staphylococcal superantigen-like protein 4. Infect Immun 80:4004-4013

238. Williams RJ, Ward JM, Henderson B, Poole S, O'Hara BP, Wilson M, Nair SP (2000) Identification of a novel gene cluster encoding staphylococcal exotoxin-like proteins: characterization of the prototypic gene and its protein product, SET1. Infect Immun 68:4407-4415

239. Koymans KJ, Bisschop A, Vughs MM, van Kessel KP, de Haas CJ, van Strijp JA (2016) Staphylococcal superantigen-like protein 1 and 5 (SSL1 \& SSL5) limit neutrophil chemotaxis and migration through MMP-inhibition. Int J Mol Sci 17(7):E1072

240. Koymans KJ, Goldmann O, Karlsson CAQ, Sital W, Thänert R, Bisschop A, Vrieling M, Malmström J, van Kessel KPM, de Haas CJC, van Strijp JAG, Medina E (2017) The TLR2 antagonist staphylococcal superantigen-like protein 3 acts as a virulence factor to promote bacterial pathogenicity in vivo. J Innate Immun 9:561-573

241. Walenkamp AM, Boer IG, Bestebroer J, Rozeveld D, TimmerBosscha H, Hemrika W, van Strijp JA, de Haas CJ (2009) 
Staphylococcal superantigen-like 10 inhibits CXCL12-induced human tumor cell migration. Neoplasia 11:333-344

242. Kurisaka C, Oku T, Itoh S, Tsuji T (2018) Role of sialic acidcontaining glycans of matrix metalloproteinase-9 (MMP-9) in the interaction between MMP-9 and staphylococcal superantigenlike protein 5. Microbiol Immunol 62:168-175

243. Zhao Y, van Kessel KPM, de Haas CJC, Rogers MRC, van Strijp JAG, Haas PA (2018) Staphylococcal superantigen-like protein 13 activates neutrophils via Formyl Peptide Receptor 2. Cell Microbiol 11:e12941

244. Bestebroer J, Poppelier MJ, Ulfman LH, Lenting PJ, Denis CV, van Kessel KP, van Strijp JA, de Haas CJ (2007) Staphylococcal superantigen-like 5 binds PSGL-1 and inhibits P-selectinmediated neutrophil rolling. Blood 109:2936-2943

245. de Haas CJ, Weeterings C, Vughs MM, de Groot PG, Van Strijp JA, Lisman T (2009) Staphylococcal superantigen-like 5 activates platelets and supports platelet adhesion under flow conditions, which involves glycoprotein Ibalpha and alpha IIb beta 3 . J Thromb Haemost 7:1867-1874

246. Li Y, Clow F, Fraser JD, Lin F (2018) Therapeutic potential of staphylococcal superantigen-like protein 7 for complementmediated hemolysis. J Mol Med (Berl) 96:965-974
247. Itoh S, Yokoyama R, Kamoshida G, Fujiwara T, Okada H, Takii T, Tsuji T, Fujii S, Hashizume H, Onozaki K (2013) Staphylococcal superantigen-like protein 10 (SSL10) inhibits blood coagulation by binding to prothrombin and factor $\mathrm{Xa}$ via their $\gamma$-carboxyglutamic acid (Gla) domain. J Biol Chem 26(288):21569-21580

248. Patel D, Wines BD, Langley RJ, Fraser JD (2010) Specificity of staphylococcal superantigen-like protein 10 toward the human IgG1 Fc domain. J Immunol 184:6283-6292

249. Valentino MD, Foulston L, Sadaka A, Kos VN, Villet RA, Santa Maria J Jr, Lazinski DW, Camilli A, Walker S, Hooper DC, Gilmore MS (2018) Genes contributing to Staphylococcus aureus fitness in abscess- and infection-related ecologies. MBio 5:e01729-e01714

250. Ibberson CB, Stacy A, Fleming D, Dees JL, Rumbaugh K, Gilmore MS, Whiteley M (2017) Co-infecting microbes dramatically alter pathogen gene essentiality during polymicrobial infection. Nat Microbiol 2:17079

251. Grosser MR, Paluscio E, Thurlow LR, Dillon MM, Cooper VS, Kawula TH, Richardson AR (2018) Genetic requirements for Staphylococcus aureus nitric oxide resistance and virulence. PLoS Pathog 14:e1006907 